\title{
Experimental investigation of dynamic impact of roadheader on floor
}

\begin{abstract}
This article presents the selected results of experimental examinations performed on the test stand in the Technological Hall of the Faculty of Mining and Geology at the Silesian University of Technology in which an R-130 roadheader (by Famur S.A.) is installed. During the examinations, the courses of dynamic load were determined in the points of the roadheader's boom support during its operation. In order to determine the impact of the cutting process on the strengths transferred onto the floor, the distribution of the static load of the roadheader's supports caused by its own weight with its changing center of gravity caused by the boom deflecting were determined. During the examinations, the size and nature of the dynamic impact of the roadheader on the floor in its support points while cutting the surface of the block made of equivalent materials (cement and sand masses) of various uniaxial compressive strength (UCS) was determined experimentally. The nature of the roadheader's chassis vibrations caused by cutting as well as the changeability of the location of its anchorage point with the movement of the cutting heads on the surface being mined result in high load fitfully in the roadheader's support points. The dynamic impact of the roadheader on the floor also has a strongly dynamic character.
\end{abstract}

Key words: roadheader, cutting process, dynamic load, floor reaction, experimental investigations

\section{INTRODUCTION}

Numerous observations of the operation of boom-type roadheaders carried out under service conditions and simulation examinations performed in various scientific centers show that the cutting process of especially rocks of low workability (hard rocks) is a source of strongly enforced vibrations and dynamic loads [1-5]. These are present mostly in the roadheader's subassemblies, including the cutting system in the form of a boom with the cutting head's drive installed on it. They are, however, transferred further on through structural joints to the turntable, the roadheader's main frame, and other of the roadheader's subassemblies connected with it. The vibrations generated by the cutting process by the roadheader's supports are transferred to the floor of the tunnel.
The component of the vibrations of the roadheader's body perpendicular to the floor is especially important from the point of view of the dynamic impact of the roadheader on the rock mass surrounding the tunnel. The high intensity of the vibrations that may lead to even a momentary loss of contact with the floor by the roadheader is a source of strong loads of an impact character. These may be the reason for the shaking of a para-seismic nature. The types of vibrations caused by human activity (including, for example, mining extraction or of a transportation origin) have a negative impact on the environment as well as the population [6-8]. The dynamic strengths of the roadheader's impact on the floor may then be the reason for its degradation as a result of exceeding its uniaxial compressive strength (UCS) or resistance to surface pressure. The effect is especially undesirable in tunnels with long service lives, as this leads to 
the necessity of floor reconstruction in order to adjust its condition to the requirements resulting from the function of the tunnels (e.g. transportational).

The roadheader is not rigidly fixed in the tunnel, so it is the frictional contact between its supports and the floor that essentially decides about maintaining stability. The contact results from the value of the friction coefficient between the surfaces that are in contact and with the roadheader's pressing force to the floor in the place of its support. The support of the roadheader on the floor when mining the surface of the heading face is performed with the use of a loading device - from the front and bracing jack(s) at the back of the roadheader. In theory, we then have the linear support along the front edge of the loading device and point support on the bracing jack. In reality, however, the loading table may also have a contact point with the floor as a result of floor irregularity or a rock mass present on it. The roadheader's body vibrations that are perpendicular to the floor surface may be the reason for the significant reduction of the frictional contact strength values and even the loss of adhesion to the floor by the roadheader in its support points. As a consequence, it will lead to a reduction or even loss of the possibility of balancing the forces that act on the roadheader's body on the plane that is parallel to the floor from mining and loss of stability by the roadheader (its uncontrolled movement along the floor surface). If this is the case, an efficient realization of the cutting process will not be possible.

Taking into account the possibility of the effective and safe mining of rocks (especially those of low workability using a boom-type roadheader), it is really important to determine the size and character of the dynamic impact of the types of machines on the floor. One of the ways of identifying the impact is to measure the reaction forces acting on the floor during the cutting process. From a technical point of view, the task is not easy to perform, especially when the measurement takes place under service conditions (in the underground roadway of a mine or while drilling a tunnel). However, the easy-to-use measuring systems that allow for the measuring of the normal floor reaction reduced to force as well as matrix sensors (measuring mats) are already known. The first ones are commonly applied to the needs of controlling the vehicle load in the road and railway transportation $[9,10]$. In turn, the measuring mats allow us to measure the pressures [11]. In the examinations on self-propelled machines, they may be used for the purposes of determining the real distribution of the machine chassis pressure on the floor. The solutions, however, are not suitable for examinations on the dynamic impact of the roadheader on the floor, as they do not allow us to measure reaction in the case of losing contact with the floor by the machine.

The measurements of the dynamic impact of the boom-type roadheader on the floor were carried out on the test stand in the Technological Hall of the Faculty of Mining and Geology at the Silesian University of Technology. They were performed while cutting on a block made of equivalent materials (cement and sand masses of various UCS) using an R-130 roadheader made by Famur S.A. In order to do this, the roadheader was placed on four supports constructed especially for it [12] - Figure 1. In each support, four tensometric single-axis (compression) force sensors have been built-in: two for measuring a)

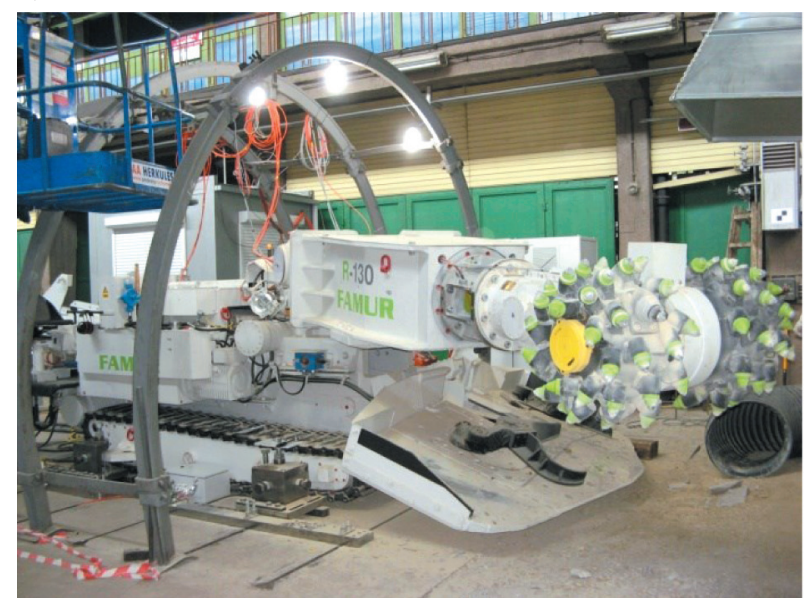

b)

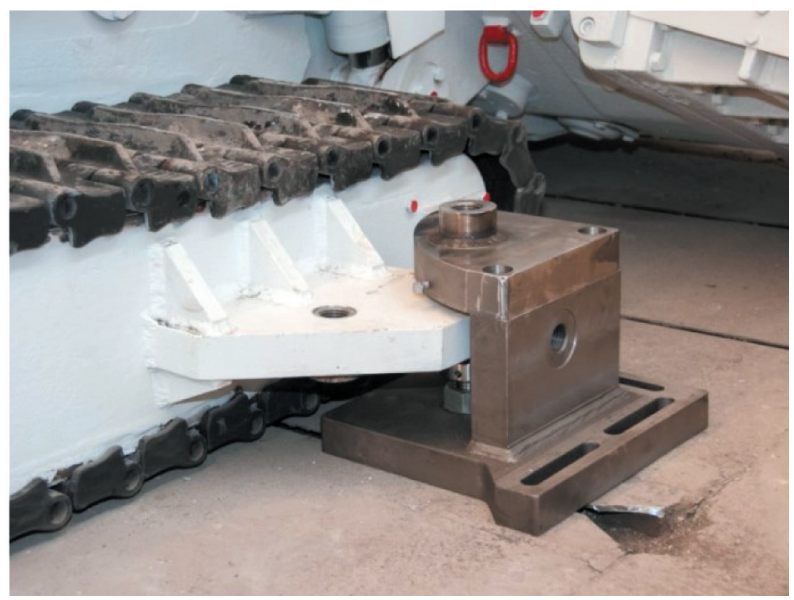

Fig. 1. Method of locating R-130 roadheader at test stand on four supports (a) and view of one support equipped with four tensometric force sensors (b) [12] 
the forces on the plane parallel to the floor (longitudinal and transverse reaction), and two for measuring the reaction perpendicular to the floor. The application of two force sensors in the direction perpendicular to the floor results from the possible return of the reaction component during the cutting process. Depending on the distribution of forces acting on the roadheader, it may be pushed in the given support point to the floor or lifted upwards. The measuring system applied during the experimental examinations allows us to determine the value of force necessary to ensure a balance in each of the roadheader's support points, even in the cases when the roadheader may lose its contact with the floor under real conditions.

The article presents the selected results of our experimental examinations. The reaction components in the roadheader's support points acting in the directions perpendicular to the floor have been analyzed.

\section{ROADHEADER'S WEIGHT LOAD ANALYSIS}

In order to identify the distribution of reactions transferred onto the floor, the roadheader was placed on a system of supports located in pairs on each side of it (Fig. 2).
The analysis of the dynamic impact of the roadheader's chassis on the floor at the support points was carried out based on a series of measurements for various boom positions while cutting on the cement and sand block. Because of the change of the boom location during the cutting process, an analysis of the impact of the boom position on the distribution of the support loads perpendicular to the floor ( $\mathrm{Z}$ axis) from the roadheader's weight was carried out first. The analysis was based on the measurements of the pressure value on the given supports with various settings of the roadheader's boom's deflecting angle in vertical plane $\alpha_{V}$ (perpendicular to the floor) and in the full range of the boom deflecting angle on the plane parallel to floor $\alpha_{H}$.

In order to determine the reference level, the courses of the forces in the supports without cutting (from the roadheader's weight) were registered. The courses of the loads in the supports towards the $\mathrm{Z}$ axis depending on the boom location that influences the location of the roadheader's center of gravity were determined. When deflecting the boom, the roadheader's center of gravity changes because of the movement of the boom and the moving part of the roadheader's turntable. Therefore, the values of the forces acting on the given supports with the boom
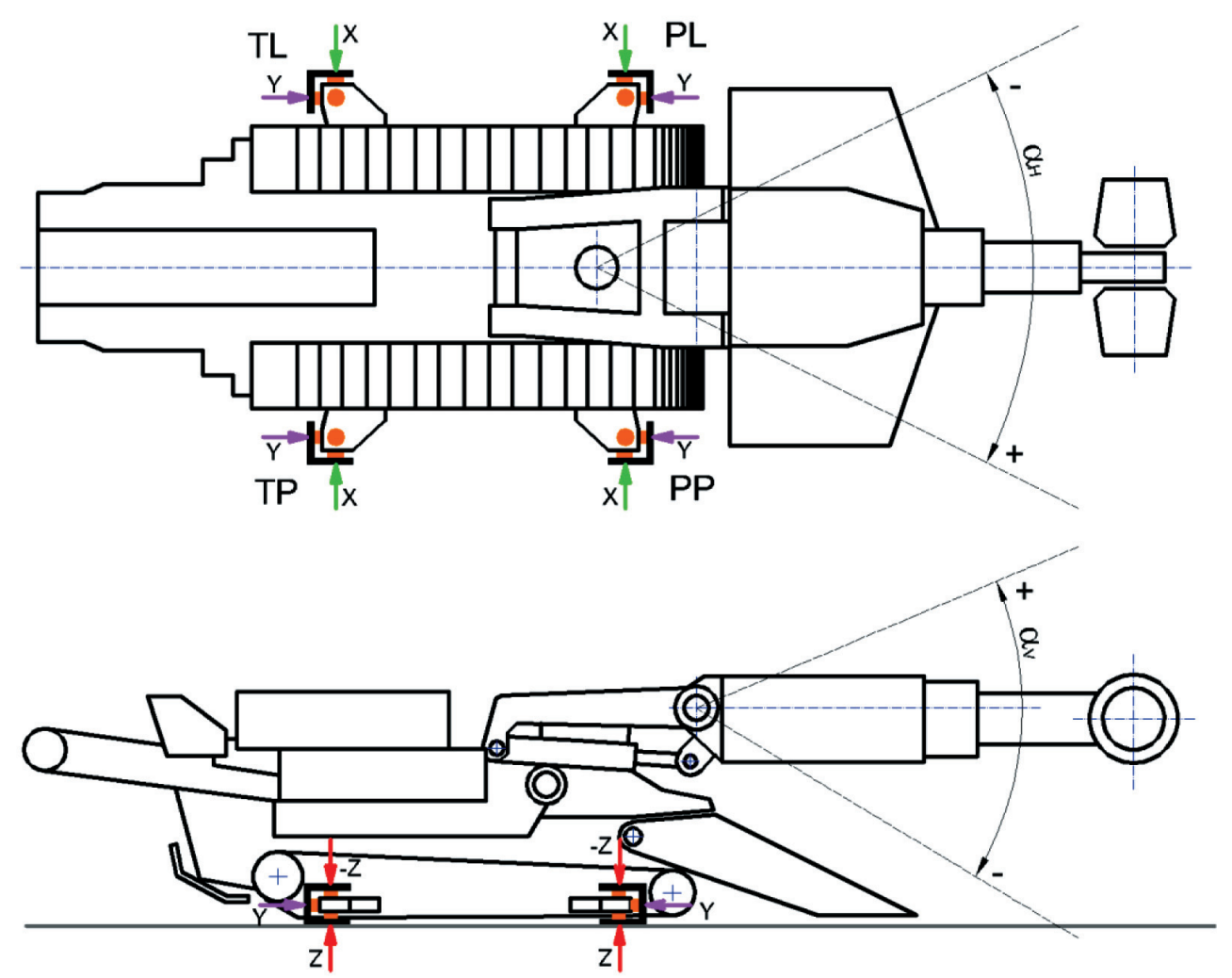

Fig. 2. Diagram of support system location and reaction directions on force sensors: $P L$ - front-left support; $P P$ - front-right support; TL - back-left support; TP - back-right support 
deflecting on the plane parallel to the floor (Fig. 3) change. The front supports (PP and PL) are the most loaded. Because of the location of the roadheader's center of gravity, their values change the most while deflecting the boom.

The four supports of the examined roadheader make up a system that is statically indeterminate; this is why the distribution of loads perpendicular to the floor on the given supports depends on the supports' performance, floor flatness, accuracy of settings of the pressure sensors, and rigidness of the roadheader's support system. In order to eliminate the impact of all of these factors, the sum of the loads in the front $(\mathrm{PP}+\mathrm{PL})$ and back supports $(\mathrm{TP}+\mathrm{TL})$ was determined, which allows for stating the location of the roadheader's center of gravity in relation to the front supports. The sum of the loads in the right $(\mathrm{PP}+\mathrm{TP})$ and left supports (PL+TL) was also de- termined, which allows for stating the distance of the center of gravity from the roadheader's longitudinal axis (Fig. 4).

The sum of the loads registered in the front $(\mathrm{PP}+\mathrm{PL})$ and back supports $(\mathrm{TP}+\mathrm{TL})$ as well as the sum of the loads registered in the right $(\mathrm{PP}+\mathrm{TP})$ and left supports (PL+TL) within the whole range of the boom deflecting on the plane parallel to the floor $-35^{\circ} \leq \alpha_{H} \leq+35^{\circ}$ (Fig. 5) for two locations of the boom on the plane perpendicular to the floor $\alpha_{V}=0^{\circ}$ (boom located horizontally) and $\alpha_{V}=+16^{\circ}$ (boom lifted upwards) are shown in Figure 4. For the boom set horizontally along the roadheader's axis $\left(\alpha_{V}=0^{\circ} ; \alpha_{H}=0^{\circ}\right)$, the cumulative load of the roadheader's front supports $(\mathrm{PP}+\mathrm{PL})$ is $232 \mathrm{kN}$, which makes up $88 \%$ of the whole roadheader's weight. The roadheader's center of gravity determined in the way referred to in [13] is located in this case at

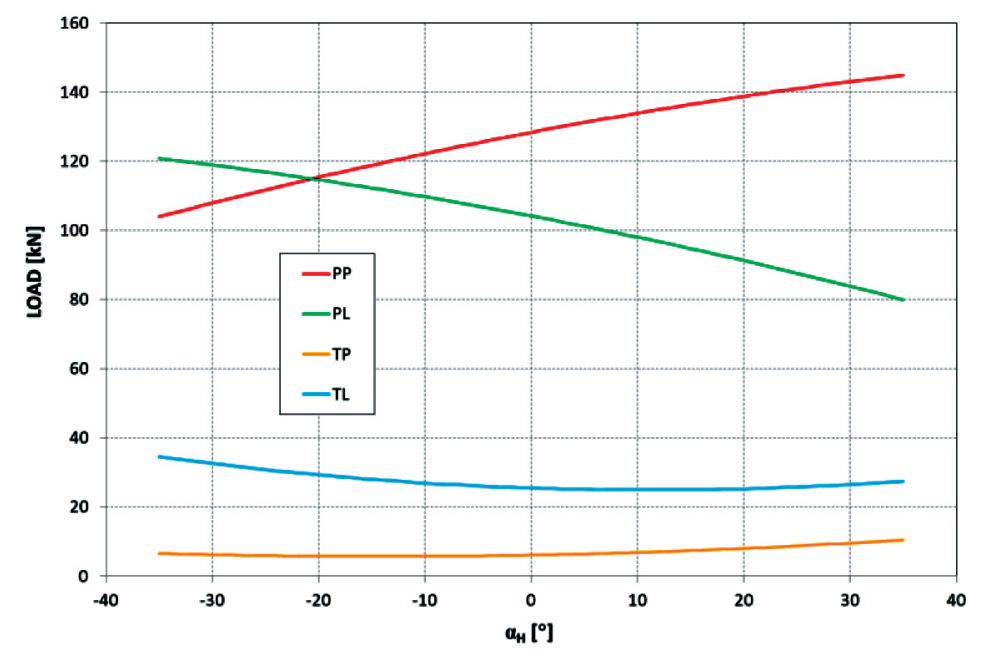

Fig. 3. Support load caused by roadheader's weight in direction perpendicular to floor (towards $Z$ axis)

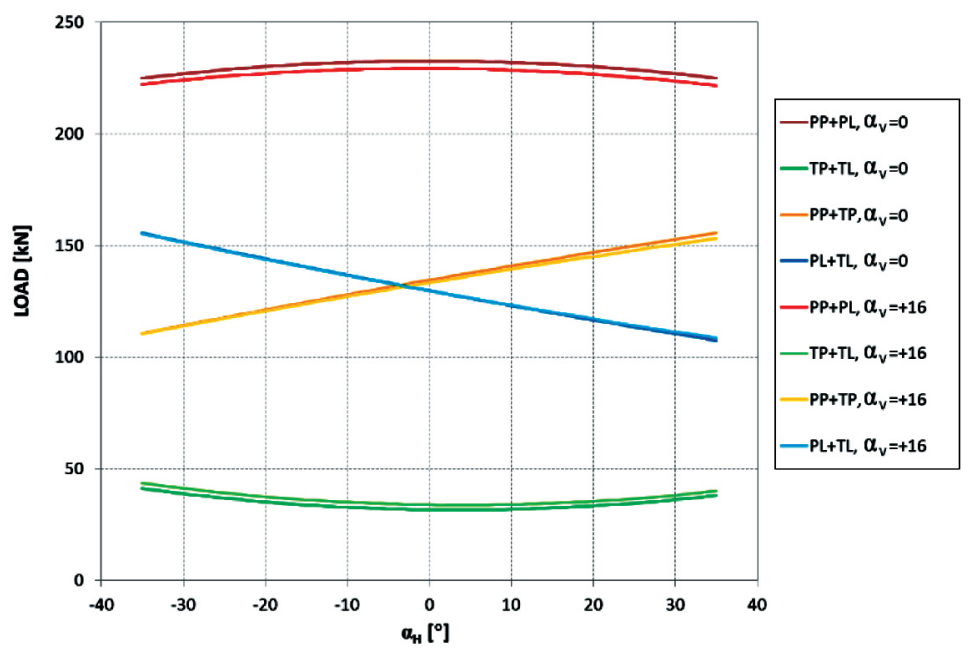

Fig. 4. Sum of registered loads of front $(P P+P L)$ and back supports $(T P+T L)$ and right $(P P+T P)$ and left supports $(P L+T L)$ caused by roadheader's weight for two boom deflecting angle values in plane perpendicular to floor $\alpha V$ 
a)
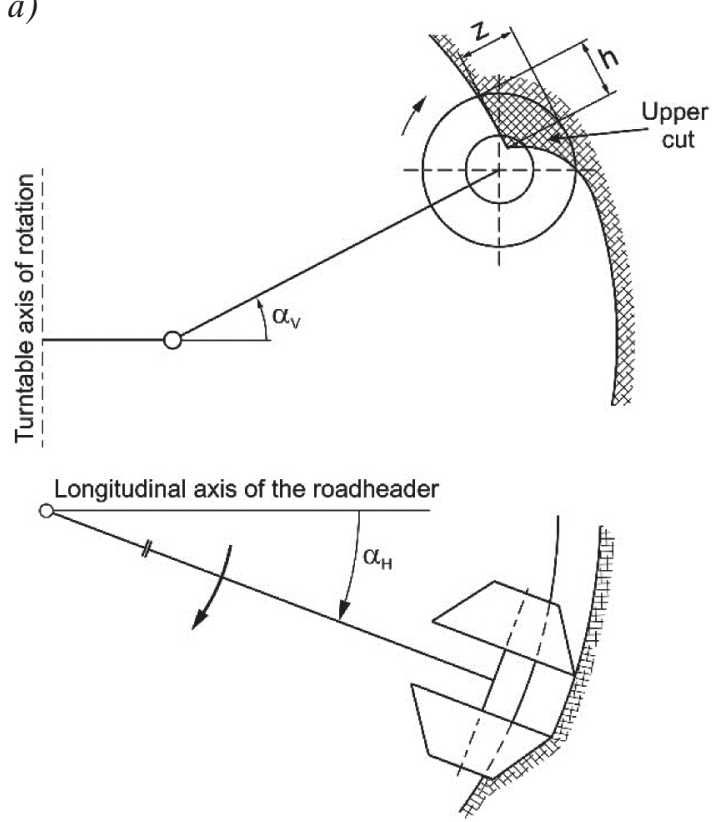

b)
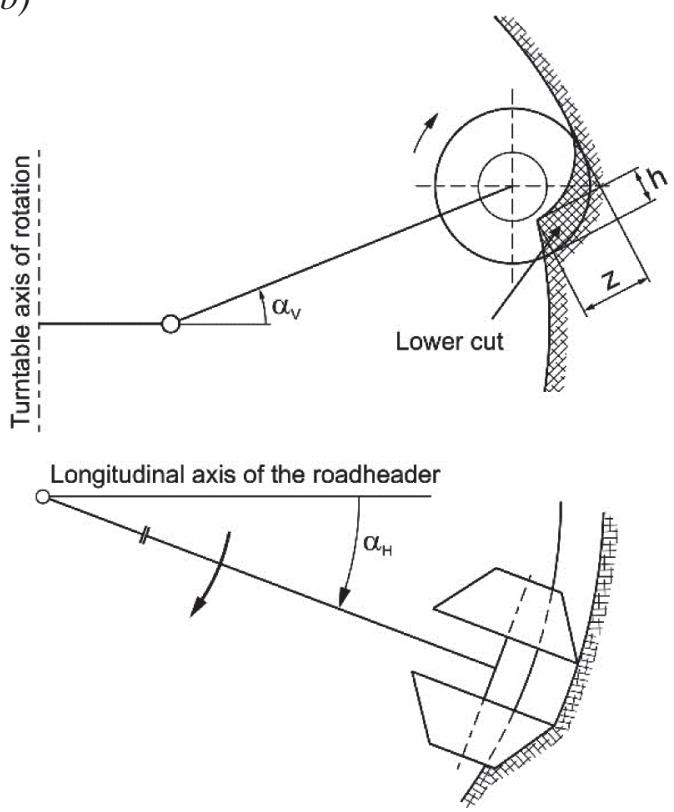

Fig. 5. Cross-sections of upper cuts (a) and lower cuts (b) performed using transverse cutting heads during their movement parallel to floor

a distance of $224 \mathrm{~mm}$ behind the front supports and $116 \mathrm{~mm}$ in front of the roadheader's turntable axis of rotation. The center of gravity is shifted $22 \mathrm{~mm}$ to the right from the roadheader's longitudinal axis as for the analyzed location of the boom. The cumulative load of the right supports (PP+TP) amounting to $134 \mathrm{kN}$ makes up $51 \%$ of the roadheader's weight. Deflecting the boom on the plane parallel to the floor from the roadheader's longitudinal axis leftwards and rightwards causes a reduction in the load of the front supports and an increase in the load of the back supports, which is the result of the dislocation of the roadheader's center of gravity towards the back supports. When deflecting the boom left, the load of the left supports significantly increases and that of right supports decreases. And so, for $\alpha_{H}=-30^{\circ}$ and $\alpha_{V}=0^{\circ}$, the load of the front supports (PP+PL) decreases by ca. $6 \mathrm{kN}$, which corresponds to the shifting of the roadheader's center of gravity backwards by $50 \mathrm{~mm}$. The load of the left supports (PL+TL) increases by $22 \mathrm{kN}$, which results in the shifting of the center of gravity leftwards by $194 \mathrm{~mm}$.

Lifting the boom upwards with an angle of $\alpha_{V}=+16^{\circ}$ moves the center of gravity towards the roadheader's rear, which causes a slight mitigation in the front supports and loading of the back supports of the roadheader. It does not, however, have a visible impact on the cumulative load of the right and left supports (Fig. 4).

\section{ANALYSIS OF DYNAMIC LOAD CAUSED BY CUTTING IN DIRECTION PERPENDICULAR TO FLOOR}

During the experimental examinations performed on the test stand, the courses of the dynamic load have been registered in the points of the roadheader's boom support during its operation. The dynamic impact of the roadheader on the floor generated by the cutting process while performing its upper and lower cuts was analyzed. The roadheader mines the soil in cuts that are parallel to the floor by means of moving the boom without changing the location of its chassis. Boom lifting or lowering after the cut at the same time determines the height of the subsequent cut. If the boom is lifted, then the next cut is an upper one, and if the boom is lowered, then the next cut is a lower cut. In the case of transverse cutting heads that work undershot while performing upper cuts, the picks perform a degressive cut (with decreasing cut depth - Fig. 5a) and while performing lower cuts, the picks cut progressively (with the increasing cut depth - Fig. 5b). And so, in both cases, the way of loading the transverse cutting heads with cutting forces is different, which influences the method of loading the roadheader's chassis in a direction perpendicular to the floor.

The cutting process is a source of strongly enforced vibrations and dynamic loads that, through 
the structural joints, are transferred further onto the turntable, the main frame of the roadheader, and other roadheader subassemblies connected with it. The vibrations generated by the cutting process by the roadheader's supports are transferred to the floor. During the examinations on the test stand while cutting on the cement and sand block using the R-130 roadheader, the forces (which are of a significant importance) transferred on the roadheader's supports perpendicular to the floor were measured and registered. Two performed cuts were analyzed when the boom was deflecting rightwards from the left side; the first cut was an upper cut, while the other was a lower cut.

With a height of $107 \mathrm{~mm}$, the upper cut was performed with the boom located on the plane perpendicular to the floor $\alpha_{V}=+7^{\circ}$ during its deflecting on the plane parallel to the floor within a range of angle $\alpha_{H}$ from $-22^{\circ}$ to $+12^{\circ}$ in 250 seconds with $10-$ second intervals (Fig. 6).

Block cutting by the transverse cutting heads of the roadheader had a significant impact on the values and character of the forces perpendicular to the floor transferred in the roadheader's support points. The mean cumulative values of the loads of the front $(\mathrm{PP}+\mathrm{PL})$ and back supports (TP+TL) change less as opposed to the cumulative mean loads of the front $(\mathrm{PP}+\mathrm{TP})$ and left supports (PL+TL) on the courses in which the change of the location of the roadheader's center of gravity is clearly marked as the boom deflecting (Fig. 6).

In order to determine the impact of the cutting process on the forces transferred onto the floor from the values of the loads measured in the supports during the cutting process, the values of the loads caused by the roadheader's weight have been deducted. Using the registered time functions of the change of the boom deflecting angle value on the plane parallel to the floor and previously specified dependencies of the cumulative loads of the front and back supports of the roadheader in the angle function, the time functions of the support loads resulting from only the cutting process were obtained (Fig. 7). The cutting forces acting on the picks located on the transverse cutting heads when performing an upper cut have a significant impact on the increase of the cumulative load of the back supports and slight mitigation on the front supports. The mean value of the back support load and front support mitigation depends on torque $M_{M}$ of the cutting system drive (course shown as orange in Figure 7). The load cumulative courses for both the front and back supports are characterized by high changeability, and their amplitude (understood as the difference between the maximum and minimum value) exceeds $40 \mathrm{kN}$.

Mining causes a significant increase in the value of the load acting perpendicularly to the floor in the supports located on the left side of the roadheader (PL+TL) as compared to the supports on the right side $(\mathrm{PP}+\mathrm{TP})$, which is the result of the boom's torque during its deflecting from the left side rightwards (Fig. 8). The courses of the cumulative forces that load the left and right supports are characterized by lower changeability than it is in the front and back supports. The reason of the differentiation of the force vibration amplitude between the front and back

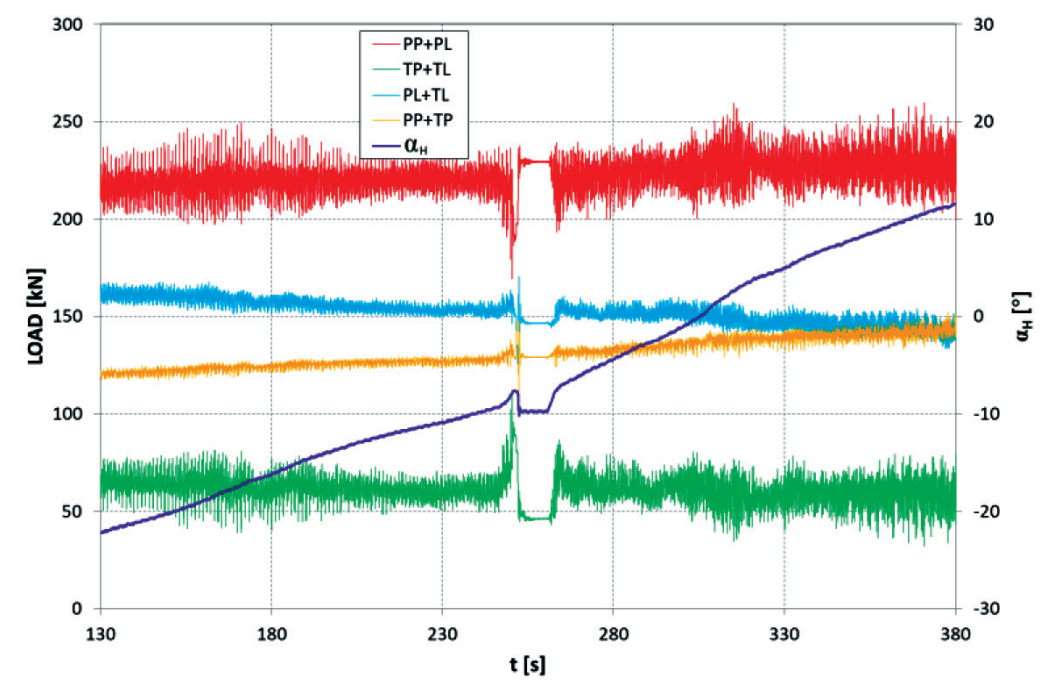

Fig. 6. Time functions of dynamic loads of front $(P P+P L)$ and back supports $(T P+T L)$ as well as right $(P P+T P)$ and left supports $(P L+T L)$ when performing upper cut 


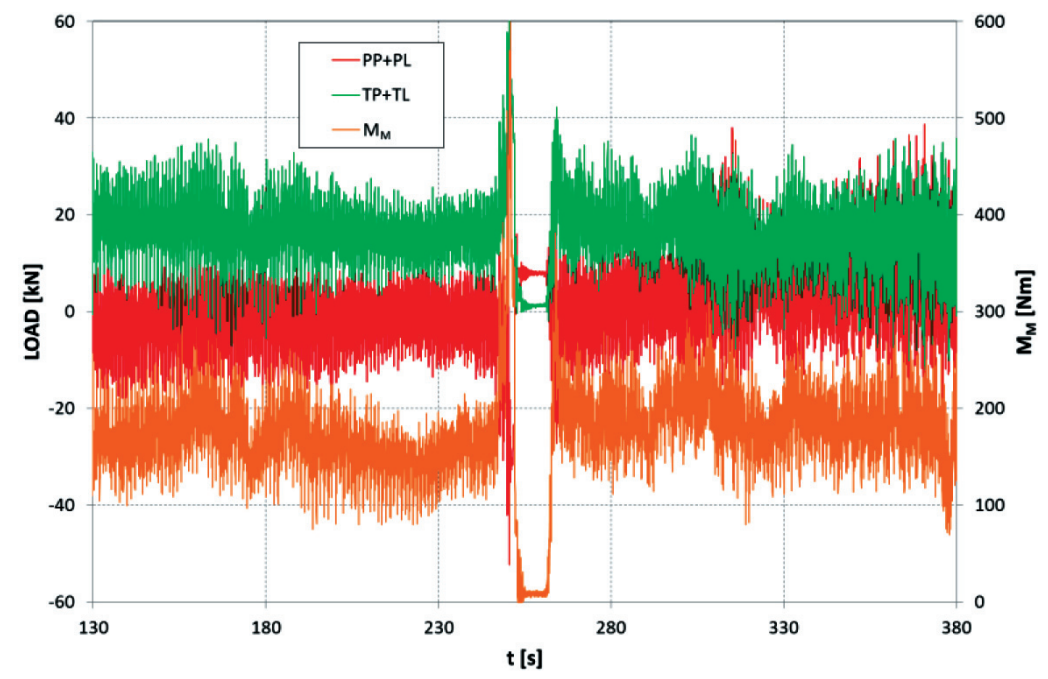

Fig. 7. Time functions of dynamic loads of front $(P P+P L)$ and back supports $(T P+T L)$ resulting from cutting process for upper cut

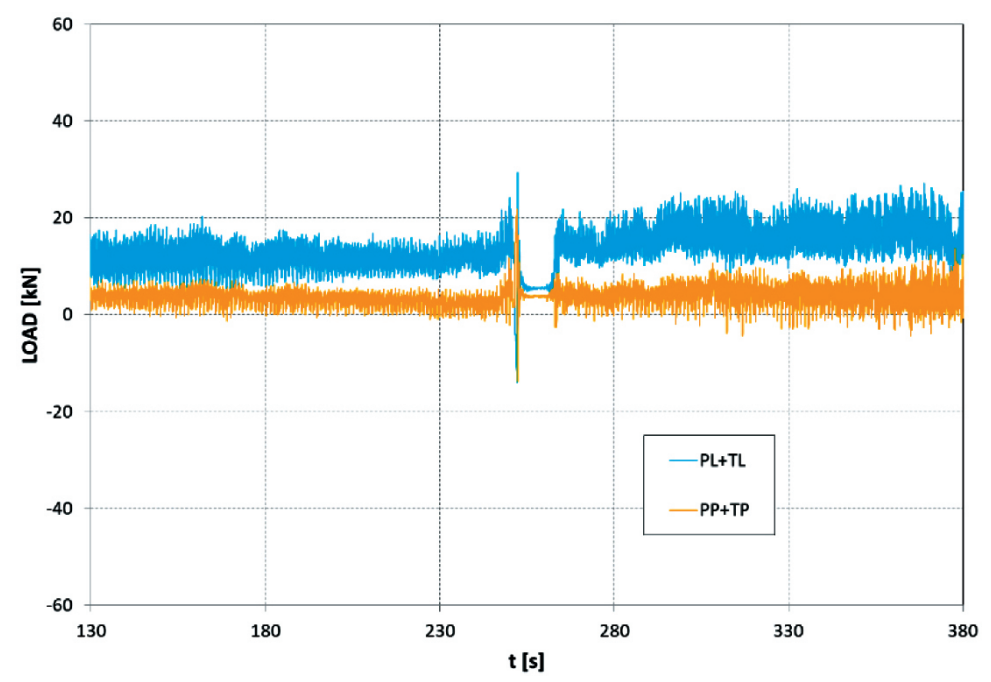

Fig. 8. Time functions of dynamic loads of right $(P P+T P)$ and left supports $(P L+T L)$ resulting from cutting process for upper cut

supports $(\mathrm{PP}+\mathrm{PL}$ and $\mathrm{TP}+\mathrm{TL}$ in Figure 7) and the right and left supports $(\mathrm{PP}+\mathrm{TP}$ and $\mathrm{PL}+\mathrm{TL}$ in Figure 8 ) is the cumulation of forces in the given supports. For the measurement fragment between the 150th and 160th second of the measurement, the time functions of the loads perpendicular to the floor have been presented separately for all supports (Fig. 9). They are characterized by a clear repeatability of a period equal to the time of the cutting head's rotation and similar changeability range. The forces in the front-right (PP) and front-left supports (PL) change in the same way. The courses are more or less a mirror reflection of the course of the cutting head's drive engine torque (momentary torque increase causes a momentary mitigation of the front supports). Meanwhile, the vibrations of the forces in the back-right (TP) and back-left supports (TL) have the same character as the course of the cutting head's drive engine torque (a momentary torque increase causes a momentary load of the back supports). This means that the vibrations of the forces in the front and back supports are mirror images, which causes that the amplitudes of the vibrations increase when cumulating the loads in the front $(\mathrm{PP}+\mathrm{PL})$ and back supports (TP+TL) while the amplitudes of the vibrations decrease when cumulating the loads in the right $(\mathrm{PP}+\mathrm{TP})$ and the left supports (PL+TL). 


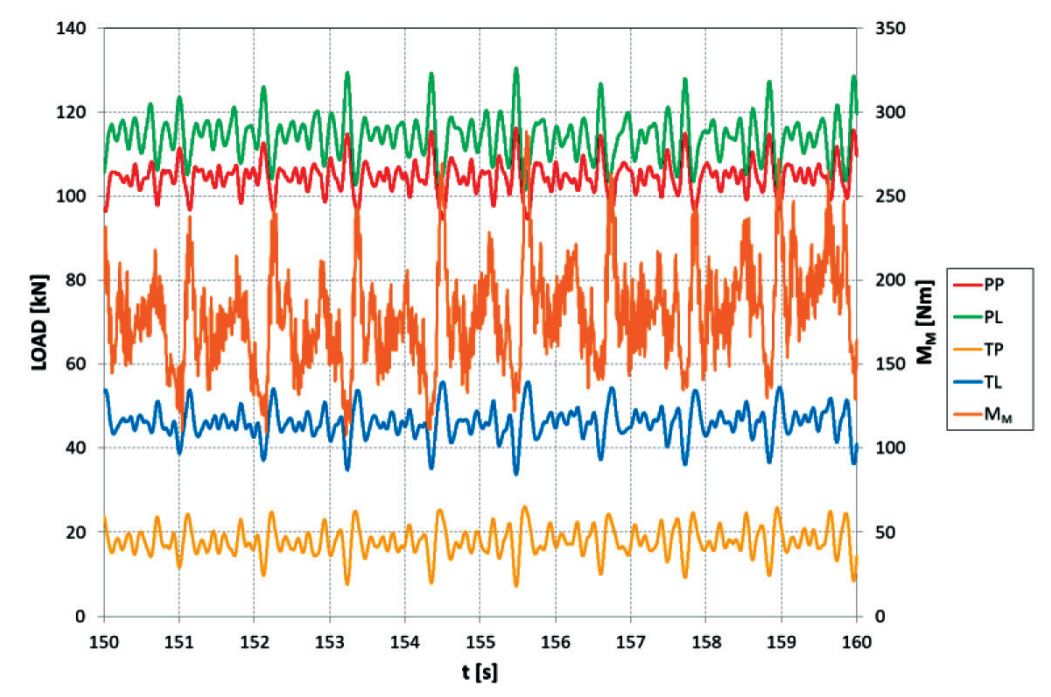

Fig. 9. Ten-second fragment of time functions for dynamic loads of roadheader's supports resulting from roadheader's weight and cutting process for upper cut

With a height of $121 \mathrm{~mm}$, the lower cut was performed with the boom located on the plane perpendicular to the floor $\alpha_{V}=-15^{\circ}$ during its deflecting on the plane parallel to the floor within the range of angles $\alpha_{H}$ from $-30^{\circ}$ to $+14^{\circ}$ in 55 seconds (Fig. 10). The performance of the lower cut using the transverse cutting heads of the roadheader had a significant impact on the values and character of the forces perpendicular to the floor transferred in the roadheader's support points. The mean values of the cumulative loads of the front $(\mathrm{PP}+\mathrm{PL})$ and back supports (TP+TL) changed mostly because of the differentiated load of the cutting system. At the same time, the value of the cumulative loads of the back supports $(\mathrm{TP}+\mathrm{TL})$, which is almost equal to the value of the cumulative loads of the front supports $(\mathrm{PP}+\mathrm{PL})$ in the 55th second of the measurement, significantly increases.

When deducting the values of the loads caused by the roadheader's weight from the values of the measured loads in the supports when cutting, the forces transferred onto the floor caused by the cutting process were determined. Using the registered time functions of the change of the boom deflecting angle value on the plane parallel to the floor as well as the previously specified dependencies of the cumulative loads of the front and back supports of the roadheader in the angle function, the time functions of the support loads resulting only from the cutting process when performing a lower cut were obtained (Fig. 11).

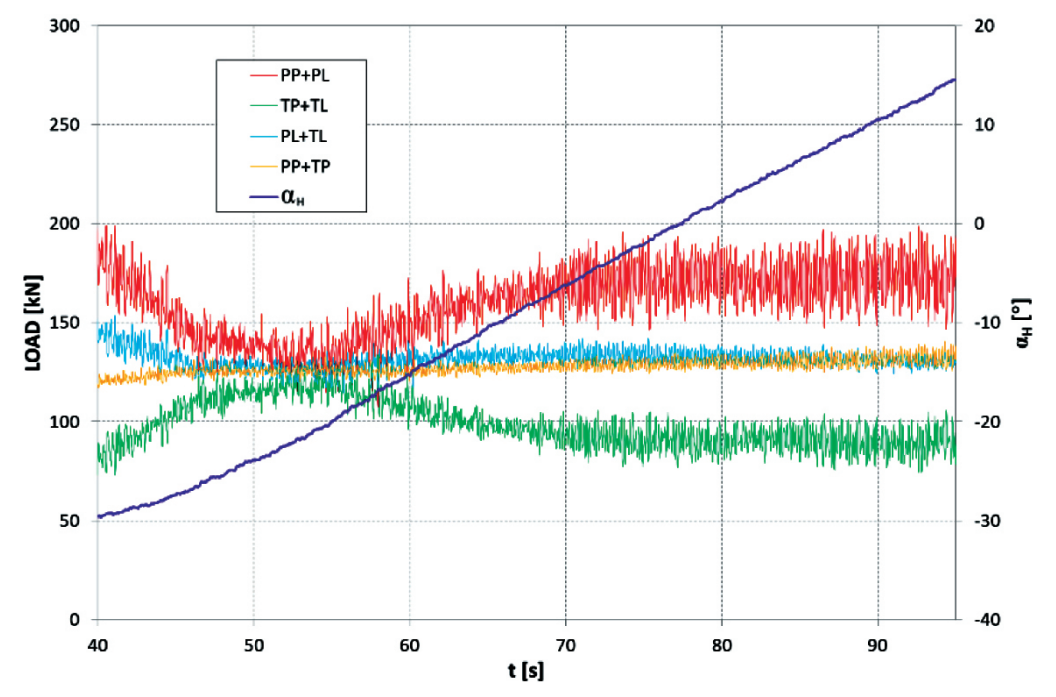

Fig. 10. Time functions of dynamic loads of front $(P P+P L)$ and back supports $(T P+T L)$ as well as right $(P P+T P)$ and left supports $(P L+T L)$ when performing lower cut 


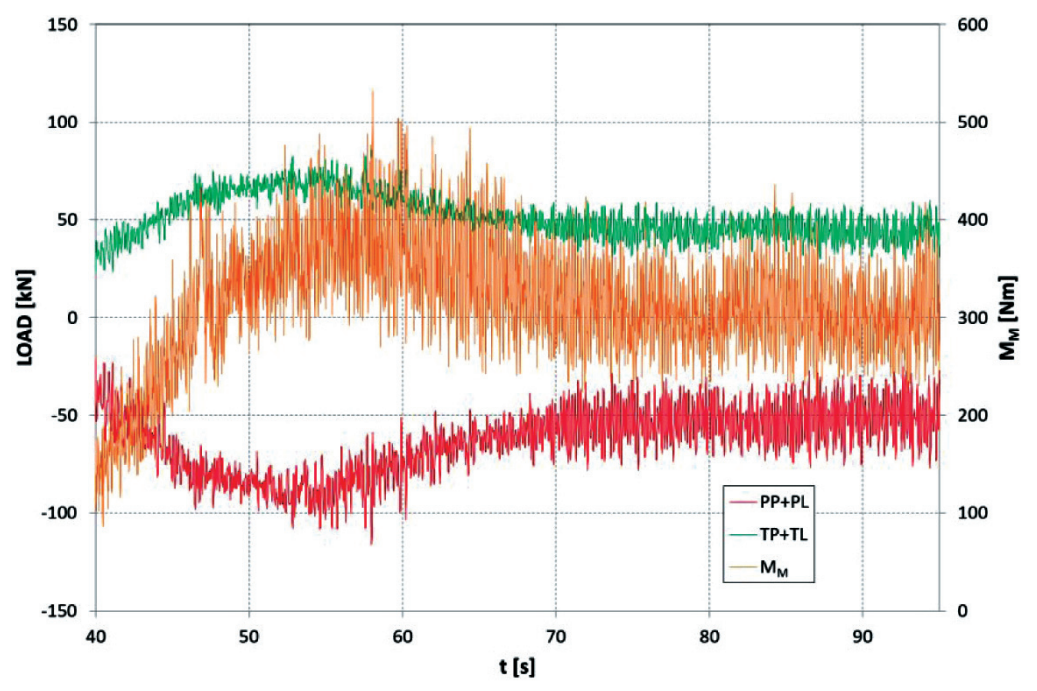

Fig. 11. Time functions of dynamic loads of front $(P P+P L)$ and back supports $(T P+T L)$ resulting from cutting process for lower cut

Just as it was with the upper cut, the cutting forces acting on the picks located on the transverse cutting heads when performing the lower cut influence an increase in the cumulative load of the back supports and mitigation of the front supports. The effect, however, is greater than in the course of the upper cut performance. The cumulative mitigation of the front supports resulting from the cutting process reaches $100 \mathrm{kN}$ in this case (if directed vertically upwards), while for the back supports, it reaches $+75 \mathrm{kN}$. The mean value of the back support load and front support mitigation is proportional here to the value of torque $M_{M}$ of the cutting system drive (course shown as orange in Figure 11).
Because of the low boom location when performing the lower cut $\left(\alpha_{V}=-15^{\circ}\right)$, the impact of the boom's torque on the distribution of the reactions perpendicular to the floor on the left and right sides of the roadheader (PL+TL and PP+TP) is small. As a result, it is the cutting vertical reaction component that determines it (Fig. 12).

The vibrations of the cumulative forces that load the left and right supports are characterized by lower changeability than in the front and back supports. This results from the cumulation of the reaction forces from the given supports.

For a ten-second measurement fragment, the time functions of the loads perpendicular to the floor have been presented separately for all supports (Fig. 13).

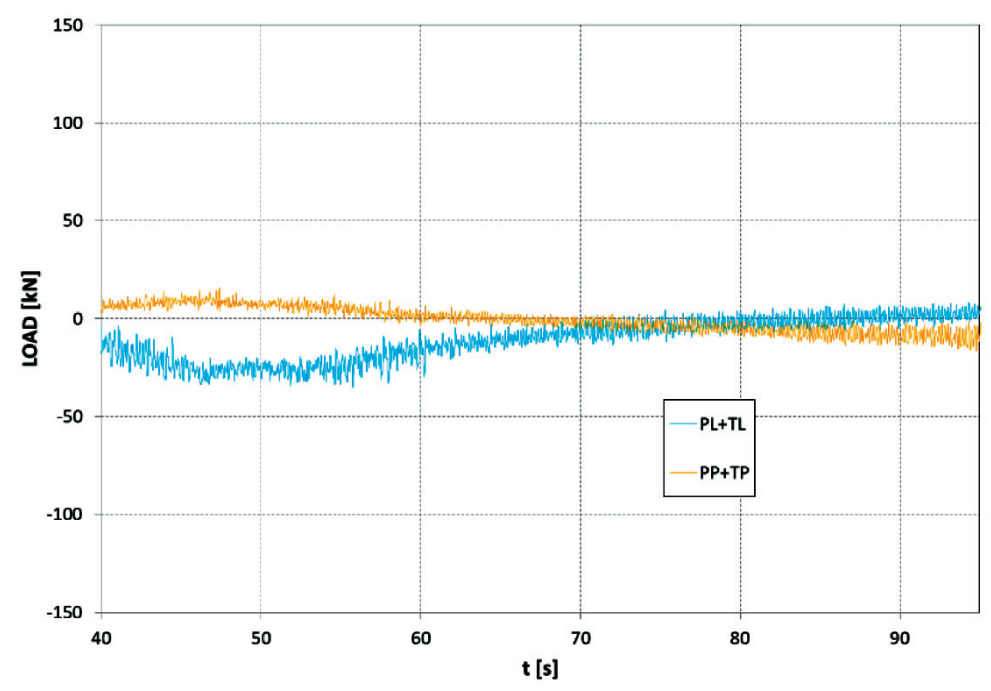

Fig. 12. Time functions of dynamic loads of right $(P P+T P)$ and left supports $(P L+T L)$ resulting from cutting process for lower cut 


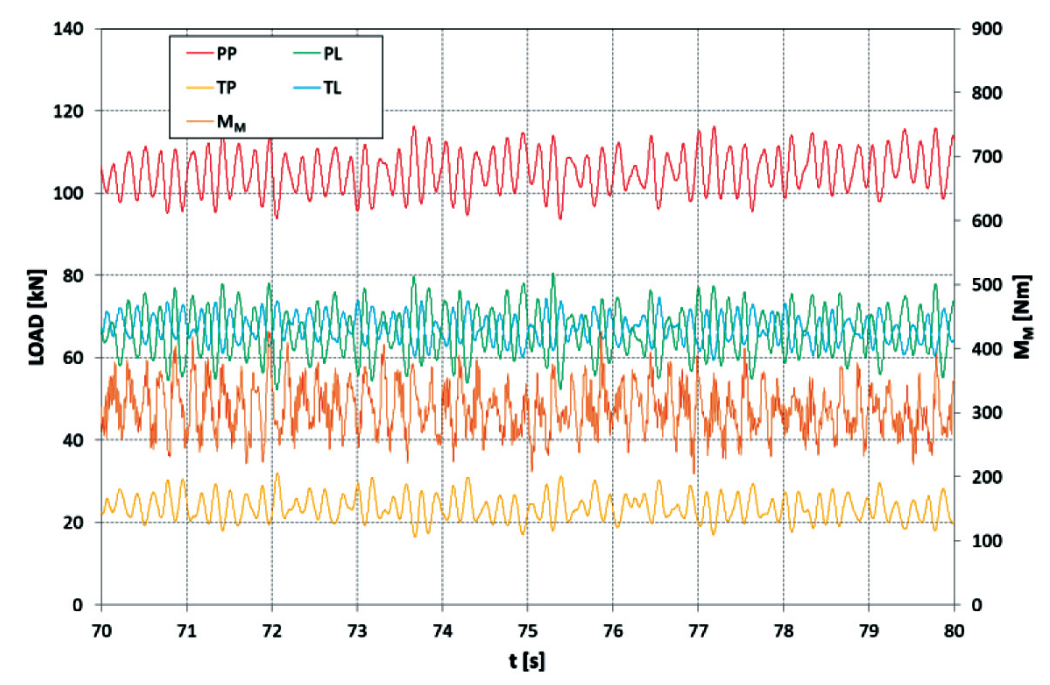

Fig. 13. Ten-second fragment of time functions for dynamic loads of roadheader's supports resulting from roadheader's weight and cutting process for lower cut

Just as it was with regard to the upper cut, the vibrations of the forces that load the supports on the plane perpendicular to the floor for the lower cut are characterized by clear repeatability, with the time period equal to the time of the cutting head's rotation and similar changeability range. The vibrations of the forces in the front-right support (PP) and front-left supports (PL) have the same character and are mirror images of the course of the drive engine's torque. The vibrations of the forces in the back-right (TP) and back-left supports (TL) also change in the same manner. The courses, however, have the same character as the course of the cutting head's drive engine torque (the momentary torque increases cause a momentary load on the back supports). The mirror image of the courses of the forces in the front and back supports causes an increase in the amplitude of the vibrations in the front $(\mathrm{PP}+\mathrm{PL})$ and back supports $(\mathrm{TP}+\mathrm{TL})$ and a decrease in the amplitude of the vibrations in the right $(\mathrm{PP}+\mathrm{TP})$ and left supports $(\mathrm{PL}+\mathrm{TL})$.

\section{SUMMARY}

The measurements of the dynamic impact of a boom-type roadheader on the floor were carried out on the test stand in the Technological Hall of the Faculty of Mining and Geology at the Silesian University of Technology. They were performed while cutting on a block made of equivalent materials (cement and sand masses of various UCS) using an R-130 roadheader made by Famur S.A.
In order to identify the distribution of the reactions transferred onto the floor, the roadheader was placed on a system of supports located in pairs on each side of it. The sum of the loads in the front $(\mathrm{PP}+\mathrm{PL})$ and back supports $(\mathrm{TP}+\mathrm{TL})$ was determined, which allows us to determine the location of the roadheader's center of gravity in relation to the front supports, and the sum of the loads in the right $(\mathrm{PP}+\mathrm{TP})$ and left supports $(\mathrm{PL}+\mathrm{TL})$, which allows us to determine the distance of the center of gravity from the roadheader's longitudinal axis.

The cutting process is a source of strongly enforced vibrations and dynamic loads that, through the structural joints, are transferred further onto the turntable, the main frame of the roadheader, and the other roadheader subassemblies connected with it. The vibrations generated by the cutting process by the roadheader's supports are transferred onto the floor of the tunnel. The vibrations transferred on the roadheader's supports perpendicular to the floor for two cuts performed when the boom was deflecting rightwards from the left side were analyzed; the first cut was an upper cut, while the other was a lower cut.

The cutting forces acting on the cutting picks located on the transverse cutting heads when performing an upper cut influence the increase of the cumulative load of the back supports and mitigation of the front supports. The mean value of the back support load and front support mitigation is proportional to the value of the torque of the cutting system drive. In order to determine the impact of the cutting process on the forces transferred onto the floor from the values 
of the loads measured in the supports during the cutting process, the values of the loads caused by the roadheader's weight have been separated. The cutting forces acting on the picks located on the transverse cutting heads when performing a lower cut influence the increase of the cumulative load of the back supports and mitigation of the front supports much more than when performing an upper cut.

For both the upper and lower cuts, the vibrations of the support loading forces on the plane perpendicular to the floor are characterized by a similar changeability range and clear repeatability (with a time period equal to the time of the cutting head's rotation). The vibrations of the forces in both front supports have the same character and are mirror images of the course of the cutting head's drive engine torque. However, the vibrations of the forces in both back supports have the same character as the course of the cutting head's drive engine torque (a momentary torque increase causes a momentary load on the back supports).

\section{Acknowledgements}

The work has been implemented under the research project titled "Control of roadheader cutting heads movement for reduction of energy consumption of mining and dynamic loads" co-financed by the National Center for Research and Development under the Applied Research Projects (agreement no. PBS3/ B2/15/2015).

\section{References}

[1] Dolipski M., Cheluszka P.: Dynamika uktadu urabiania kombajnu chodnikowego, Wydawnictwo Politechniki Śląskiej, Gliwice 2002.

[2] Lansheng Zhang, Yuanyu Zhao, XiushanTang, Qiang Liu, Miao Cao, Miao Wu.: Load Spectrum Research of Roadheader Cutting Header based on Rain Flow Method, in: Proceedings of 2016 International Congress on Computation Algorithms in Engineering (ICCAE 2016), June 25-26 2016, Bangkok, Thailand, 401-406.
[3] Wei Wang, Lin Yan, Tianzheng Wang, Shaoping Guan, Chao Zhang, Ying Zhang, Dawei Wang: Dynamic load identification method of rock roadheader using multi neural network and evidence theory, in: Proceedings on 2016 IEEE International Conference on Mechatronics and Automation, August 7-10 2016, Harbin, China, 1238-1243.

[4] Yi Liu, Yang Gao, Yingying Zhang, Jiaxing Fu, Chuanhui Huang: Working Vibration Analysis of the Bearing Plate on Roadheader Test Bed, "MATEC Web of Conferences" 2015, 25, 03019: 6.

[5] Zhao Xuelei, Liu He, Li Weitao: Load Torque Observer for Cutting Motor of Roadheader Based on PLL, in: Proceedings of Third International Conference on Measuring Technology and Mechatronics Automation, January 6-7 2011, Shangshai, China, 476-480.

[6] Kogut J.: Analiza spektrum odpowiedzi drgań drogowych, Politechnika Krakowska, Kraków 1999 [Ph.D. thesis].

[7] Mrozek D.: Nieliniowa analiza numeryczna dynamicznej odpowiedzi uszkodzonych budynków, Politechnika Śląska, Gliwice 2010 [Ph.D. thesis].

[8] Nader M.: Oddziaływania dynamiczne wybranych środków transportu na budynki i ludzi, na przyktadzie badań węzta komunikacyjnego, in: Proceeding of International Scientific Conference "Transport of the 21st century", 18-21.09.2007, Stare Jabłonki, Poland, 2007.

[9] Burnos P.: Autokalibracja systemów ważących pojazdy samochodowe w ruchu oraz analiza I korekcja wptywu temperatury na wynik ważenia, AGH, Kraków 2009 [Ph.D. thesis].

[10] Wiśnicki B., Wolnowska A.: The systems of automatic weight control of vehicles in the road and rail transport in Poland, "LogForum" 2011, 7, 3, 3: 25-33. http://www.logforum.net/ vol7/issue3/no3.

[11] Postolache O., Girão P.S.: Calibration and application of a pressure mapping sensor, in: Proceedings of IMEKO 2010 TC3, TC5 and TC22 Conferences "Metrology in Modern Context”, November 22-25 2010, Pattaya, Chonburi, Thailand, 329-332.

[12] Cheluszka P., Remiorz E.: Test stand for determining dynamic loads transmitted to the floor while roadheader operation, "Technicka Diagnostika" 2016, 25, 1: 62-70.

[13] Dolipski M., Sobota P.: Badania zmiany położenia środka ciężkości kombajnu chodnikowego, "Maszyny Górnicze" 1998, 72: 23-29.

PIOTR CHELUSZKA, Ph.D. DSc. Eng., Assoc. prof. PIOTR SOBOTA, Ph.D., Eng. GRZEGORZ GŁUSZEK, M.Sc., Eng. Department of Mining Mechanisation and Robotisation Faculty of Mining and Geology Silesian University of Technology ul. Akademicka 2, 44-100 Gliwice, Poland \{Piotr.Cheluszka, Piotr.Sobota, Grzegorz.Gluszek\}@polsl.pl 


\title{
Doświadczalne badania oddziaływania dynamicznego kombajnu chodnikowego na podłoże
}

\begin{abstract}
$W$ artykule przedstawiono wybrane wyniki badań eksperymentalnych zrealizowanych na stanowisku badawczym w Hali Technologicznej Wydziału Górnictwa i Geologii, na którym zainstalowany jest kombajn chodnikowy R-130 (prod. Famur S.A.). W trakcie tych badań wyznaczone zostały przebiegi obciażenia dynamicznego $w$ punktach podparcia wysiegnikowego kombajnu chodnikowego podczas realizacji przezeń procesu roboczego. $W$ celu określenia wptywu procesu urabiania na sity przenoszone na podtoże wyznaczono rozkład obciążenia statycznego podpór kombajnu od ciężaru własnego przy zmieniajacym się położeniu jego środka ciężkości spowodowanym wychylaniem wysięgnika. W trakcie badań wyznaczono doświadczalnie wielkość oraz charakter oddziaływania dynamicznego kombajnu na podtoże w punktach jego podparcia podczas urabiania powierzchni bloku wykonanego $z$ materiałów ekwiwalentnych (mas cementowo-piaskowych) o różnej wytrzymatości na ściskanie. Charakter wymuszenia drgań nadwozia kombajnu od urabiania oraz zmienność potożenia jego punktu zaczepienia w miarę przemieszczania głowic urabiających po urabianej powierzchni skutkuja duża nierównomiernościa obciqżenia $w$ punktach podparcia kombajnu. Oddziaływanie dynamiczne kombajnu na podłoże ma przy tym silnie dynamiczny charakter.
\end{abstract}

Słowa kluczowe: kombajn chodnikowy, urabianie, obciążenie dynamiczne, reakcja podtoża, badania doświadczalne

\section{WPROWADZENIE}

Liczne obserwacje pracy wysięgnikowych kombajnów chodnikowych prowadzone w warunkach eksploatacyjnych oraz realizowane w różnych ośrodkach naukowych badania symulacyjne wskazują na to, iż proces urabiania w szczególności skał trudno urabialnych jest źródłem silnych drgań wymuszonych oraz obciążeń dynamicznych [1-5]. Podlegają im główne podzespoły kombajnu, $w$ tym przede wszystkim układ urabiania w postaci wysięgnika z zainstalowanym w nim napędem głowic urabiających. Przez więzy konstrukcyjne przenoszone są one jednak dalej na obrotnicę, ramę główną kombajnu oraz pozostałe, związanie z nią podzespoły kombajnu. Drgania powstałe $\mathrm{w}$ wyniku urabiania przekazywane są przez podpory kombajnu na spąg drążonego wyrobiska korytarzowego lub tunelu. Szczególnie istotne znaczenie, ze względu na oddziaływanie dynamiczne kom- bajnu na górotwór otaczający drążone wyrobisko, ma składowa drgań kadłuba kombajnu prostopadła do podłoża. Duża intensywność tych drgań, które mogą prowadzić nawet do chwilowej utraty przez kombajn kontaktu z podłożem, jest bowiem źródłem silnych obciążeń o charakterze udarowym. Mogą one być przyczyną wstrząsów o charakterze parasejsmicznym. Wstrząsy tego rodzaju wywołane działalnością człowieka (w tym na przykład eksploatacją górniczą czy też pochodzenia komunikacyjnego) mają negatywny wpływ na środowisko i ludzi [6-8]. Siły dynamicznego oddziaływania kombajnu na spąg mogą więc być przyczyną jego degradacji na skutek przekroczenia wytrzymałości na ściskanie czy wytrzymałości na naciski powierzchniowe. Jest to niepożądane, szczególnie w przypadku wyrobisk i tuneli o długim okresie eksploatacji, gdyż pociąga za sobą konieczność rekonstrukcji spągu w celu dostosowania jego stanu do wymagań wynikających z funkcji (np. komunikacyjnych) tych wyrobisk. 
Kombajn chodnikowy w drążonym przezeń wyrobisku nie jest w żaden sposób sztywno utwierdzony, zatem o zachowaniu stateczności decyduje w dużej mierze sprzężenie cierne pomiędzy jego podporami i spągiem. Sprzężenie to wynika z kolei z wartości współczynnika tarcia pomiędzy stykającymi się ze sobą powierzchniami oraz siły docisku kombajnu do spagu w miejscu jego podparcia. Podparcie wysięgnikowego kombajnu chodnikowego na spągu podczas urabiania powierzchni czoła przodku odbywa się z wykorzystaniem stołu ładowarki - z przodu oraz stopy stabilizującej (jednej bądź dwóch) - z tyłu kombajnu. Teoretycznie zatem mamy do czynienia z podparciem liniowym wzdłuż przedniej krawędzi stołu ładowarki oraz podparciem punktowym na stopie stabilizującej. W rzeczywistości jednak, na skutek nierówności spągu czy zalegających na nim ziaren urobku, stół ładowarki może mieć również punktowy styk ze spagiem. Drgania kadłuba kombajnu w kierunku prostopadłym do powierzchni spągu mogą być przyczyną znacznego spadku wartości sił sprzężenia ciernego, a nawet utraty przez kombajn przyczepności do podłoża w punktach jego podparcia. Prowadzić to będzie w konsekwencji do spadku, czy wręcz utraty możliwości zrównoważenia sił działających na kadłub kombajnu w płaszczyźnie równoległej do spągu od urabiania oraz utraty stateczności przez kombajn (niekontrolowanego jego przemieszczania się po powierzchni spągu). Skuteczna realizacja procesu urabiania nie będzie w takim przypadku możliwa.

Ze względu na możliwość efektywnego i bezpiecznego urabiania skał (zwłaszcza trudno urabialnych) wysięgnikowym kombajnem chodnikowym, określenie wielkości i charakteru oddziaływania dynamicznego tego rodzaju maszyn na spąg jest zagadnieniem niezmiernie istotnym. Jedną z dróg identyfikacji tego

a)

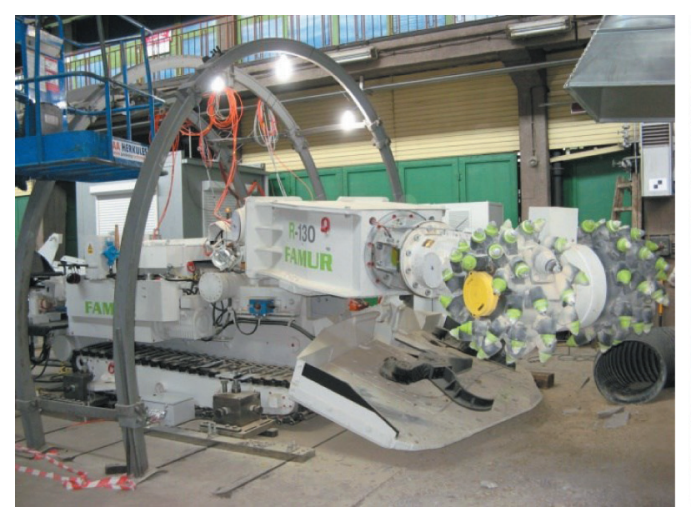

oddziaływania jest pomiar sił reakcji działających na podłoże $w$ trakcie realizacji przezeń procesu roboczego. $\mathrm{Z}$ technicznego punktu widzenia nie jest to zadanie łatwe do wykonania, zwłaszcza gdy pomiar ten miałby się odbywać w warunkach eksploatacyjnych (w wyrobisku podziemnym kopalni lub podczas drążenia tunelu). Znane są wprawdzie proste w użyciu układy pomiarowe pozwalające na pomiar zredukowanej do siły skupionej reakcji normalnej podłoża oraz czujniki matrycowe (maty pomiarowe). Pierwsze z wymienionych rozwiązań są powszechnie stosowane do kontroli obciążenia pojazdów w transporcie drogowym i kolejowym $[9,10]$. Maty pomiarowe umożliwiają z kolei pomiar nacisków [11]. W badaniach maszyn samojezdnych mogą być one wykorzystane do wyznaczenia rzeczywistego rozkładu nacisków podwozia maszyny na podłoże. Rozwiązania te nie nadają się jednak do badań oddziaływania dynamicznego kombajnu chodnikowego na podłoże, gdyż nie pozwalają na pomiar reakcji w przypadku utraty kontaktu maszyny z tym podłożem.

Pomiary sił oddziaływania dynamicznego wysięgnikowego kombajnu chodnikowego na podłoże przeprowadzone zostały na stanowisku badawczym w Hali Technologicznej Wydziału Górnictwa i Geologii Politechniki Śląskiej. Dokonane one zostały w trakcie urabiania bloku wykonanego z materiałów ekwiwalentnych (mas cementowo-piaskowych o różnej wytrzymałości na ściskanie) kombajnem chodnikowym R-130 (prod. Famur SA). W tym celu kombajn posadowiony został na czterech specjalnie skonstruowanych podporach [12] - rysunek 1. W każdej z tych podpór zabudowane zostały cztery tensometryczne jednoosiowe czujniki siły (nacisku) - dwa do pomiaru sił w płaszczyźnie równoległej do podłoża (reakcji wzdłużnej i poprzecznej) oraz dwa do pomiaru reakcji

b)

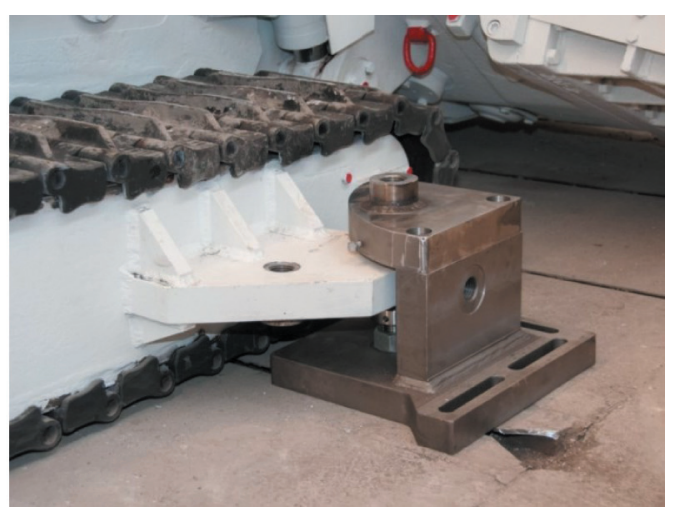

Rys. 1. Sposób posadowienia kombajnu chodnikowego R-130 na stanowisku badawczym na czterech podporach (a) oraz widok jednej z podpór wyposażonej w cztery tensometryczne czujniki sity (b) [12] 
w kierunku prostopadłym do podłoża. Zastosowanie dwóch czujników siły na kierunku prostopadłym do podłoża wynika z możliwego zwrotu tej składowej reakcji w trakcie realizacji procesu urabiania. W zależności bowiem od układu sił działających na kombajn może on być dociskany w danym punkcie podparcia do podłoża bądź podnoszony w górę. Wykorzystany w trakcie badań doświadczalnych układ pomiarowy pozwala zatem na określenie w każdym z punktów podparcia kombajnu wartości siły niezbędnej do zapewnienia stanu równowagi, nawet w przypadku gdy w warunkach rzeczywistych kombajn może stracić kontakt z podłożem.

W niniejszym artykule przedstawiono wybrane wyniki badań doświadczalnych. Analizie poddano składowe reakcji w punktach podparcia kombajnu działające w kierunkach prostopadłych do podłoża.

\section{ANALIZA OBCIAZŻENIA CIĘŻAREM KOMBAJNU}

W celu identyfikacji rozkładu reakcji przenoszonych na podłoże kombajn został posadowiony na zespole podpór rozmieszczonych po dwie na każdej stronie kombajnu (rys. 2).

Analiza oddziaływania dynamicznego nadwozia kombajnu chodnikowego na podłoże w punktach pod- parcia została przeprowadzona na podstawie serii pomiarów przy różnych ustawieniach wysięgnika, w trakcie urabiania bloku cementowo-piaskowego. Ze względu na zmianę położenia wysięgnika w trakcie urabiania, na wstępie przeprowadzono analizę wpływu ustawienia wysięgnika na rozkład obciążenia podpór w kierunku prostopadłym do podłoża (oś Z) od ciężaru kombajnu. Analizę oparto na pomiarach wartości nacisku na poszczególne podpory, przy różnych ustawieniach kąta wychylenia wysięgnika kombajnu w płaszczyźnie pionowej $\alpha_{V}$ (prostopadłej do podłoża) i w pełnym zakresie kąta wychylenia wysięgnika w płaszczyźnie równoległej do podłoża $\alpha_{H}$.

W celu ustalenia poziomu odniesienia zarejestrowano przebiegi sił w podporach bez urabiania (od ciężaru kombajnu). Wyznaczono przebiegi obciążeń w podporach w kierunku osi $\mathrm{Z}$ w zależności od położenia wysięgnika, które wpływa na położenie środka ciężkości kombajnu. Podczas wychylania wysięgnika środek ciężkości kombajnu zmienia swoje położenie ze względu na przemieszczanie masy wysięgnika i części ruchomej obrotnicy kombajnu. Zmieniają się więc wartości sił działających na poszczególne podpory w miarę wychylania wysięgnika w płaszczyźnie równoległej do podłoża (rys. 3). Najbardziej obciążone są podpory przednie (PP i PL). Ze względu na położenie środka ciężkości kombajnu ich wartości zmieniają się w największym stopniu podczas wychylania wysięgnika.
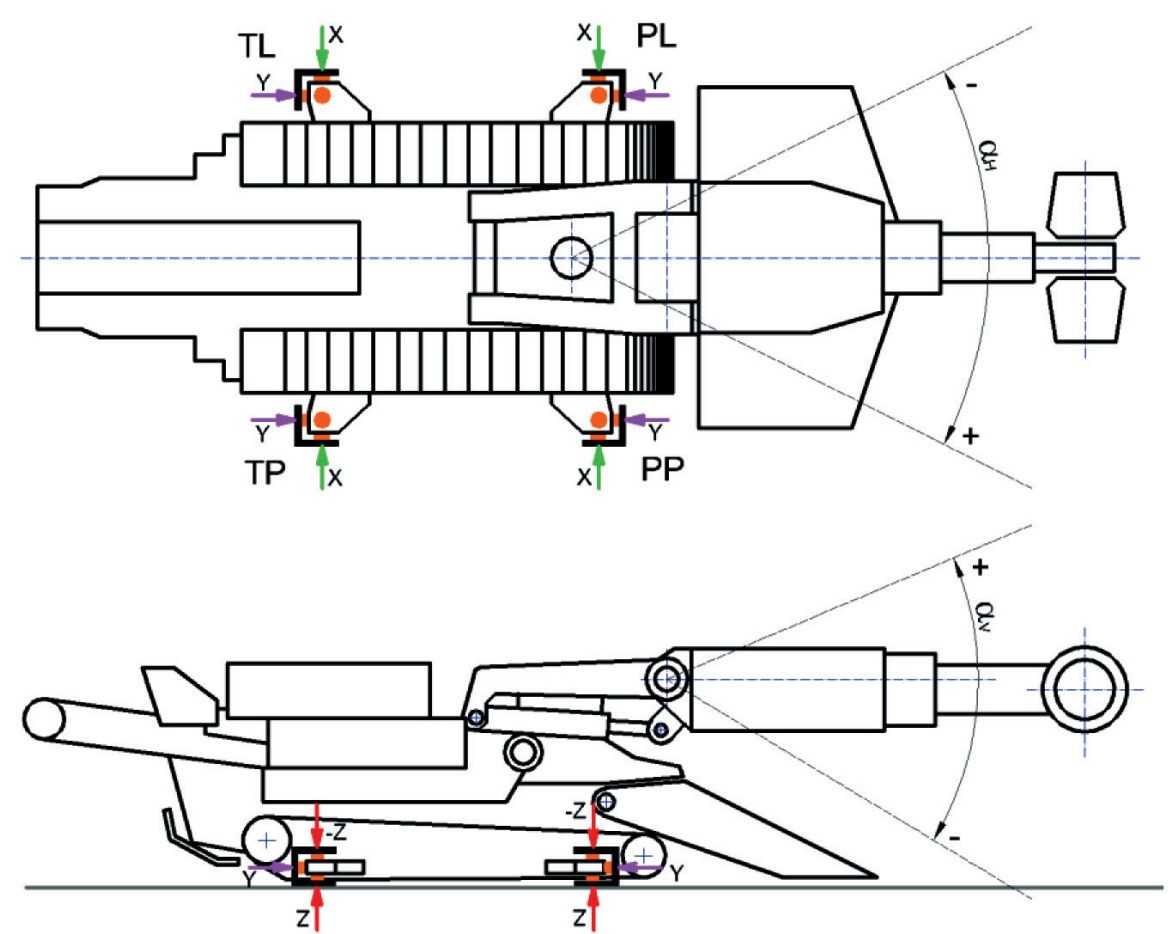

Rys. 2. Schemat rozmieszczenia zespołów podpór i kierunki reakcji na czujnikach sily: PL - podpora przednia lewa, $P P$ - podpora przednia prawa, $T L$ - podpora tylna lewa, TP - podpora tylna prawa 
Podparcie badanego kombajnu chodnikowego na czterech podporach tworzy układ statycznie niewyznaczalny i dlatego rozkład obciążeń prostopadłych do podłoża na poszczególne podpory zależy od dokładności wykonania podpór, płaskości podłoża, dokładności ustawienia czujników nacisku i sztywności układu podparcia kombajnu. Aby zniwelować wpływ wszystkich tych czynników, wyznaczono sumę obciążeń w podporach przednich $(\mathrm{PP}+\mathrm{PL})$ i tylnych (TP+TL), co pozwala określić położenie środka ciężkości kombajnu względem podpór przednich. Wyznaczono również sumę obciążeń w podporach prawych (PP+TP) i lewych (PL+TL), co pozwala określić odległość środka ciężkości od osi wzdłużnej kombajnu (rys. 4).
Sumę obciążeń zarejestrowanych w podporach przednich $(\mathrm{PP}+\mathrm{PL})$ i tylnych $(\mathrm{TP}+\mathrm{TL})$ oraz sumę obciążeń zarejestrowanych $\mathrm{w}$ podporach prawych (PP+TP) i lewych (PL+TL), w całym zakresie wychylania wysięgnika w płaszczyźnie równoległej do podłoża: $-35^{\circ} \leq \alpha_{H} \leq+35^{\circ}$ (rys. 5), dla dwóch położeń wysięgnika w płaszczyźnie prostopadłej do podłoża $\alpha_{V}=0^{\circ}$ (wysięgnik ustawiony poziomo) i $\alpha_{V}=+16^{\circ}$ (wysięgnik podniesiony w górę) pokazano na rysun$\mathrm{ku}$ 4. Dla wysięgnika ustawionego poziomo wzdłuż osi kombajnu $\left(\alpha_{V}=0^{\circ}, \alpha_{H}=0^{\circ}\right)$ sumaryczne obciążenie podpór przednich kombajnu (PP+PL) wynosi 232 kN, co stanowi 88\% całego ciężaru kombajnu. Środek ciężkości kombajnu wyznaczony w sposób opisany w pracy [13] znajduje się w tym przypadku

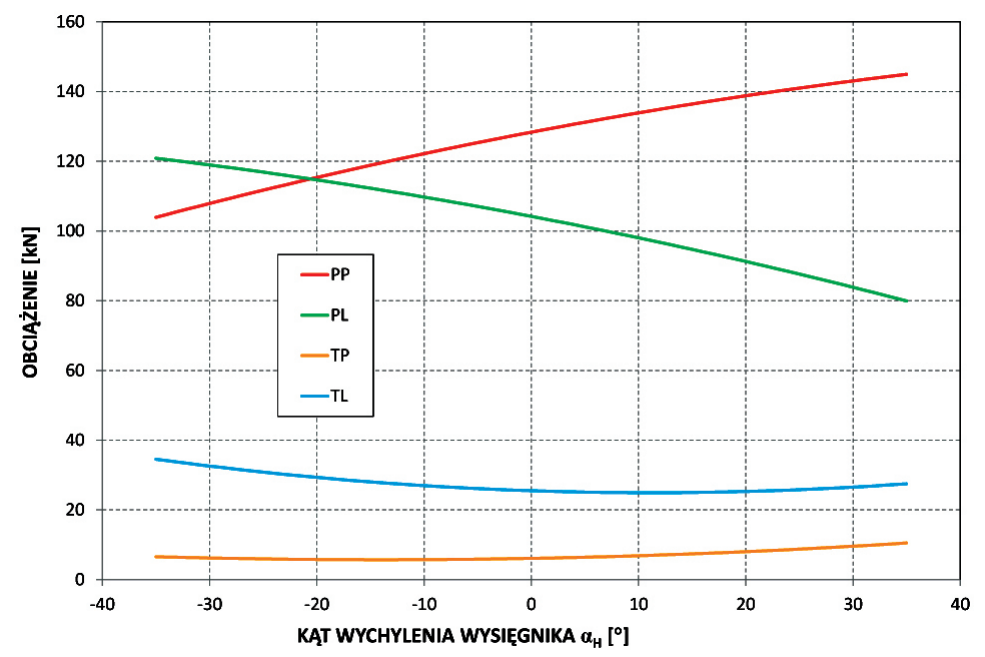

Rys. 3. Obciążenia podpór od ciężaru kombajnu w kierunku prostopadtym do podłoża (w kierunku osi Z)

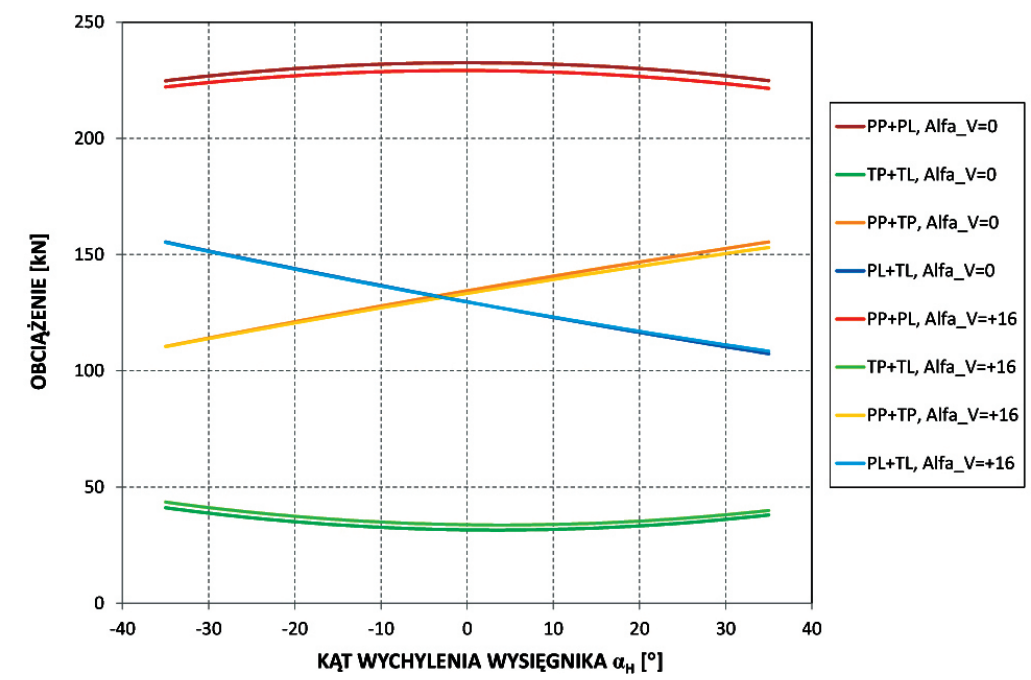

Rys. 4. Suma zarejestrowanych obciązeń podpór przednich $(P P+P L)$ i tylnych $(T P+T L)$ oraz prawych $(P P+T P)$ i lewych $(P L+T L)$ od ciężaru kombajnu dla dwóch wartości kąta wychylania wysięgnika w płaszczyźnie prostopadtej do podtoża $\alpha \mathrm{V}$ 
a)

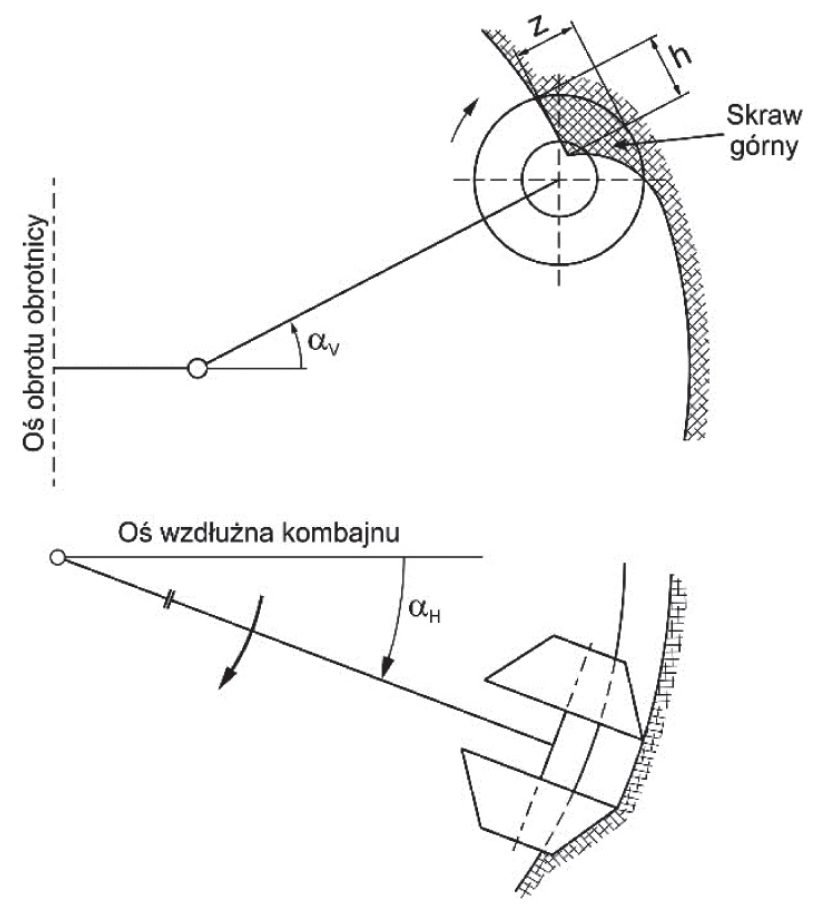

b)

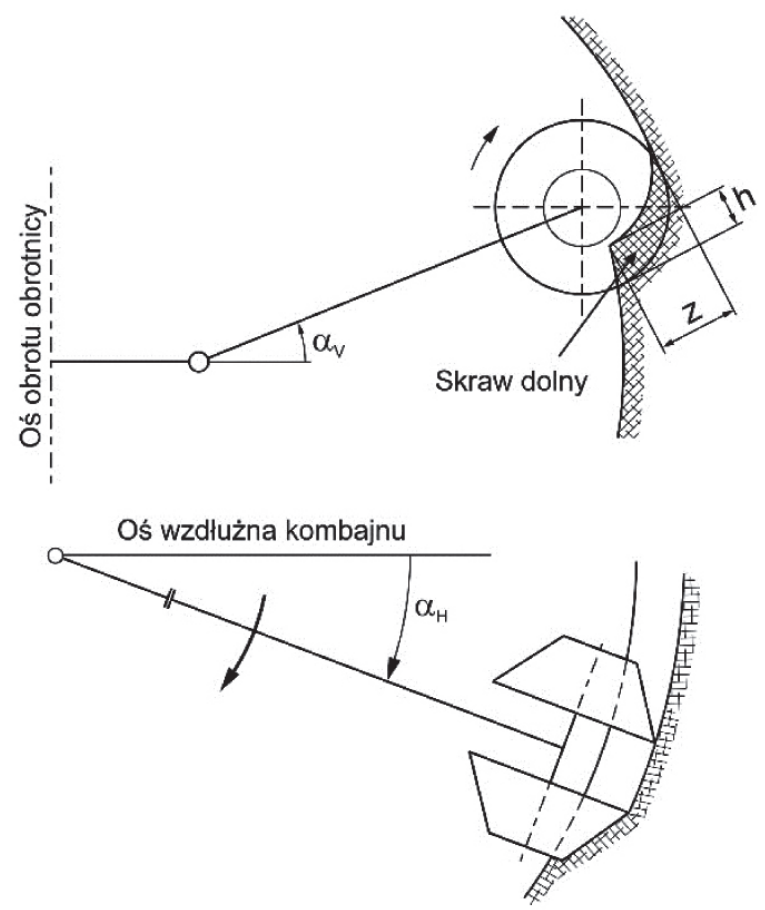

Rys. 5. Przekroje poprzeczne skrawów górnych (a) oraz dolnych (b) wykonywanych poprzecznymi głowicami urabiającymi podczas ich przemieszczania równolegle do spagu (podłoża)

w odległości $224 \mathrm{~mm}$ za przednimi podporami oraz $116 \mathrm{~mm}$ przed osią obrotu obrotnicy kombajnu. Środek ciężkości jest przesunięty o $22 \mathrm{~mm}$ w prawo od osi wzdłużnej kombajnu, gdyż dla analizowanego położenia wysięgnika sumaryczne obciążenie podpór prawych (PP+TP) wynoszące $134 \mathrm{kN}$ stanowi 51\% ciężaru kombajnu. Wychylanie wysięgnika w płaszczyźnie równoległej do podłoża od osi wzdłużnej kombajnu w lewo i w prawo powoduje zmniejszanie obciążenia podpór przednich i wzrost obciążenia podpór tylnych, co jest wynikiem przesuwania się środka ciężkości kombajnu w stronę tylnych podpór. Przy wychylaniu wysięgnika w lewo znacznie wzrasta obciążenie podpór lewych i zmniejsza się obciążenie podpór prawych. I tak, dla $\alpha_{H}=-30^{\circ}$ i $\alpha_{V}=0^{\circ}$ obciążenie podpór przednich $(\mathrm{PP}+\mathrm{PL})$ zmniejsza się o około $6 \mathrm{kN}$, co odpowiada przesunięciu środka ciężkości kombajnu ku tyłowi o $50 \mathrm{~mm}$. Obciążenie podpór lewych (PL+TL) zwiększa się przy tym o $22 \mathrm{kN}$ skutkiem przemieszczenia środka ciężkości w lewo o $194 \mathrm{~mm}$.

Podniesienie wysięgnika w górę o kąt $\alpha_{V}=+16^{\circ}$ przesuwa środek ciężkości ku tyłowi kombajnu, co powoduje niewielkie odciążenie podpór przednich i dociążenie podpór tylnych kombajnu. Nie ma to natomiast widocznego wpływu na sumaryczne obciążenie podpór prawych i lewych (rys. 4).

\section{ANALIZA OBCIAZŻENIA DYNAMICZNEGO OD URABIANIA W KIERUNKU PROSTOPADŁYM DO PODŁOŻA}

W trakcie badań eksperymentalnych zrealizowanych na stanowisku badawczym zarejestrowano przebiegi obciążenia dynamicznego w punktach podparcia wysięgnikowego kombajnu chodnikowego podczas jego procesu roboczego. Przeanalizowano oddziaływanie dynamiczne kombajnu chodnikowego na podłoże generowane procesem urabiania podczas wykonywania skrawu górnego i dolnego. Kombajn chodnikowy urabia caliznę skrawami równoległymi do podłoża przez manewrowanie wysięgnikiem bez zmiany położenia podwozia kombajnu. Podniesienie lub opuszczenie wysięgnika po wykonaniu skrawu determinuje przy tym wysokość kolejnego skrawu. Jeżeli wysięgnik jest podnoszony, to kolejny skraw jest skrawem górnym, a jeżeli wysięgnik jest opuszczany, to kolejny skraw jest skrawem dolnym. W przypadku głowic poprzecznych urabiających podsiębiernie przy realizacji skrawu górnego noże skrawają degresywnie (ze zmniejszającą się głębokością skrawania) (rys. 5a), zaś przy realizacji skrawu dolnego progresywnie (ze zwiększającą się głębokością skrawania) (rys. 5b). Odmienny jest w obydwóch 
przypadkach sposób obciążenia głowic poprzecznych siłami urabiania, co wpływa na sposób obciążenia podwozia kombajnu w kierunku prostopadłym do podłoża.

Proces urabiania jest źródłem silnych drgań wymuszonych oraz obciążeń dynamicznych, które poprzez więzy konstrukcyjne przenoszone są dalej na obrotnicę, ramę główną kombajnu oraz pozostałe, związane z nią podzespoły kombajnu. Drgania generowane procesem urabiania przez podpory kombajnu przekazywane są na spąg drążonego wyrobiska. Podczas badań stanowiskowych urabiania bloku cementowo-piaskowego kombajnem chodnikowym R-130 mierzono i rejestrowano, mające szczególnie istotne znaczenie, siły przenoszone na podpory kombajnu prostopadle do podłoża. Analizie poddano dwa skrawy zrealizowane podczas wychylania wysięgnika od lewej strony w prawo, przy czym pierwszy skraw był skrawem górnym, a drugi - skrawem dolnym.

Skraw górny o wysokości 107 mm był wykonany przy ustawieniu wysięgnika w płaszczyźnie prostopadłej do podłoża $\alpha_{V}=+7^{\circ}$ podczas wychylania wysięgnika w płaszczyźnie równoległej do podłoża w zakresie kąta $\alpha_{H}$ od $-22^{\circ}$ do $+12^{\circ} \mathrm{w}$ czasie 250 sekund z 10-sekundową przerwą (rys. 6).

Skrawanie bloku przez poprzeczne głowice urabiające kombajnu istotnie wpływa na wartości i charakter sił prostopadłych do podłoża przenoszonych w punktach podparcia kombajnu. Średnie wartości sumarycznych obciążeń podpór przednich (PP+PL) i tylnych (TP+TL) zmieniają się w niewielkim stopniu w odróżnieniu od sumarycznych średnich obciążeń podpór prawych (PP+TP) i lewych (PL+TL), na których przebiegach wyraźnie zaznacza się zmiana położenia środka ciężkości kombajnu w miarę wychylania wysięgnika (rys. 6).

W celu określenia wpływu procesu urabiania na siły przenoszone na podłoże od wartości zmierzonych obciążeń w podporach w trakcie urabiania odjęto wartości obciążeń wywołanych ciężarem kombajnu. Wykorzystując zarejestrowany przebieg czasowy zmiany wartości kąta wychylania wysięgnika w płaszczyźnie równoległej do spągu i wyznaczone wcześniej zależności sumarycznych obciążeń podpór przednich i tylnych kombajnu w funkcji tego kąta, uzyskano przebiegi czasowe obciążeń podpór wynikające tylko z procesu urabiania (rys. 7). Siły urabiania działające na noże skrawające rozmieszczone na głowicach poprzecznych podczas wykonywania skrawu górnego wpływają na istotne zwiększenie sumarycznego obciążenia podpór tylnych i nieznaczne odciążenie podpór przednich. Średnia wartość obciążenia podpór tylnych i odciążenia podpór przednich zależna jest przy tym od wartości momentu obrotowego $M_{M}$ silnika układu urabiania (przebieg w kolorze brązowym na rysunku 7). Przebiegi sumarycznego obciążenia zarówno podpór przednich, jak i tylnych charakteryzują się dużą zmiennością, a ich amplituda (rozumiana jako różnica wartości maksymalnej i minimalnej) przekracza $40 \mathrm{kN}$.

Urabianie powoduje znaczne zwiększenie wartości obciążenia działającego prostopadle do podłoża w podporach $\mathrm{z}$ lewej strony kombajnu (PL+TL) w porównaniu $\mathrm{z}$ podporami po stronie prawej $(\mathrm{PP}+\mathrm{TP})$, co jest wynikiem działania momentu obrotu wysięgnika podczas wychylania wysięgnika od lewej strony w prawo (rys. 8).

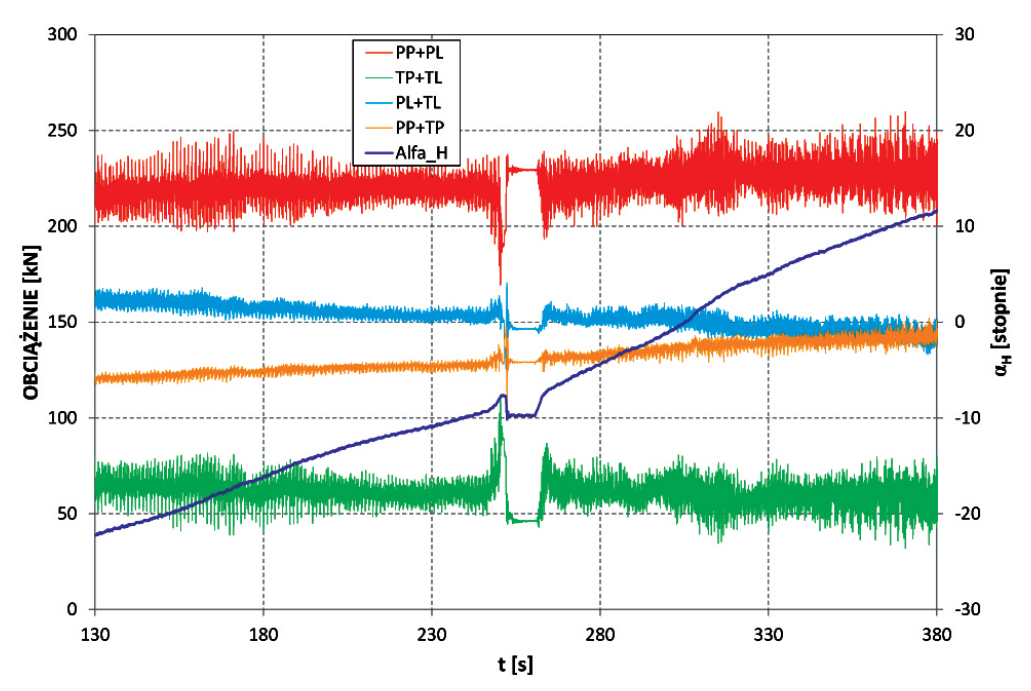

Rys. 6. Przebiegi czasowe obciążeń dynamicznych podpór przednich $(P P+P L)$ i tylnych $(T P+T L)$ oraz prawych $(P P+T P)$ i lewych $(P L+T L)$ podczas wykonywania skrawu górnego 


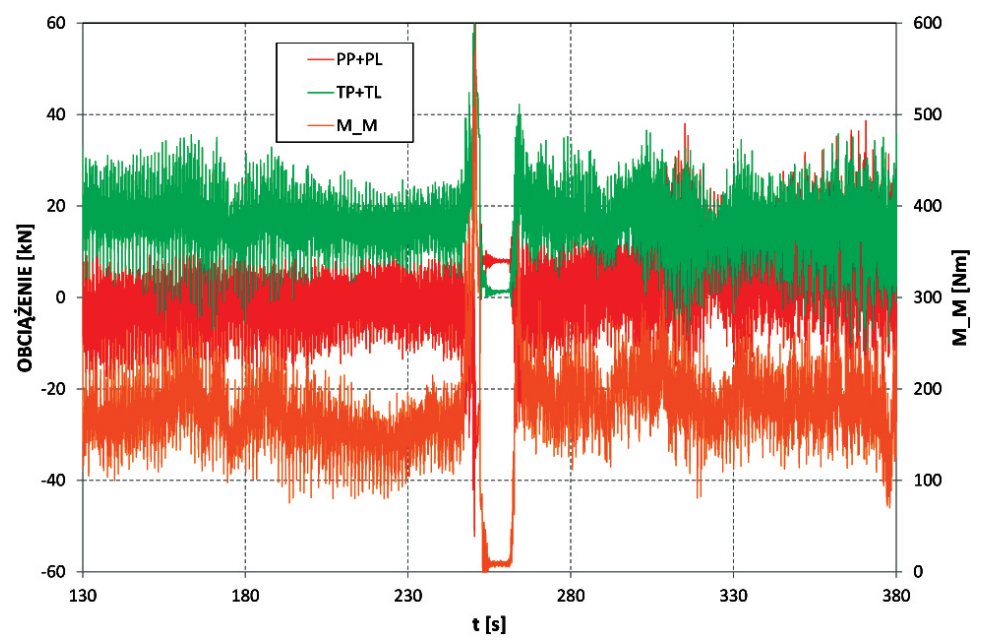

Rys. 7. Przebiegi czasowe obciażeń dynamicznych podpór przednich $(P P+P L)$ i tylnych $(T P+T L)$ wynikające z procesu urabiania dla skrawu górnego

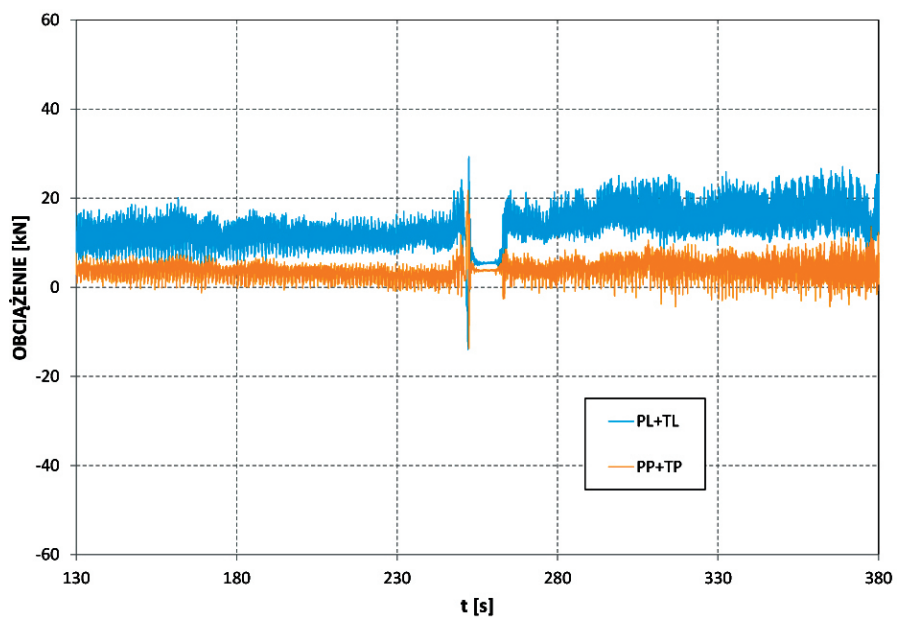

Rys. 8. Przebiegi czasowe obciażeń dynamicznych podpór prawych $(P P+T P)$ i lewych $(P L+T L)$ wynikajace z procesu urabiania dla skrawu górnego

Przebiegi sumarycznych sił obciążających podpory lewe i prawe charakteryzują się mniejszą zmiennością niż w przypadku podpór przednich i tylnych. Powodem zróżnicowania amplitud drgań sił pomiędzy podporami przednimi i tylnymi ( $\mathrm{PP}+\mathrm{PL}$ i $\mathrm{TP}+\mathrm{TL}$ na rys. 7$)$ a podporami prawymi i lewymi (PP+TP i PL+TL na rysunku 8) jest sumowanie sił w poszczególnych podporach. Dla fragmentu pomiaru pomiędzy 150 a 160 sekundą pomiaru przedstawiono przebiegi czasowe obciążeń prostopadłych do podłoża, oddzielnie dla wszystkich podpór (rys. 9). Charakteryzują się one wyraźną powtarzalnością o okresie równym czasowi obrotu głowicy i zbliżonym zakresem zmienności. Siły w podporze przedniej prawej (PP) i podporze przedniej lewej (PL) zmieniają się w taki sam sposób. Przebiegi te są $\mathrm{w}$ przybliżeniu lustrzanym odbiciem przebiegu momentu obrotowego silnika napędu głowic (chwilowy wzrost momentu obrotowego powoduje chwilowe odciążenie podpór przednich). Natomiast drgania sił w podporze tylnej prawej (TP) i podporze tylnej lewej (TL) mają ten sam charakter co przebieg momentu obrotowego silnika napędu głowic (chwilowy wzrost momentu obrotowego powoduje chwilowe dociążenie podpór tylnych). Oznacza to, że drgania sił w podporach przednich i tylnych są lustrzanym odbiciem, co powoduje przy sumowaniu obciążeń w podporach przednich $(\mathrm{PP}+\mathrm{PL})$ i tylnych $(\mathrm{TP}+\mathrm{TL})$ zwiększenie amplitud drgań, zaś przy sumowaniu obciążeń w podporach prawych $(\mathrm{PP}+\mathrm{TP})$ i lewych $(\mathrm{PL}+\mathrm{TL})$ zmniejszanie amplitud drgań.

Skraw dolny o wysokości $121 \mathrm{~mm}$ był wykonany przy ustawieniu wysięgnika w płaszczyźnie prostopadłej do podłoża $\alpha_{V}=-15^{\circ}$ podczas wychylania wysięgnika w płaszczyźnie równoległej do podłoża w zakresie kątów $\alpha_{H}$ od $-30^{\circ}$ do $+14^{\circ}$ w czasie $55 \mathrm{~s}$ (rys. 10). Wykonanie skrawu dolnego poprzecznymi głowicami 


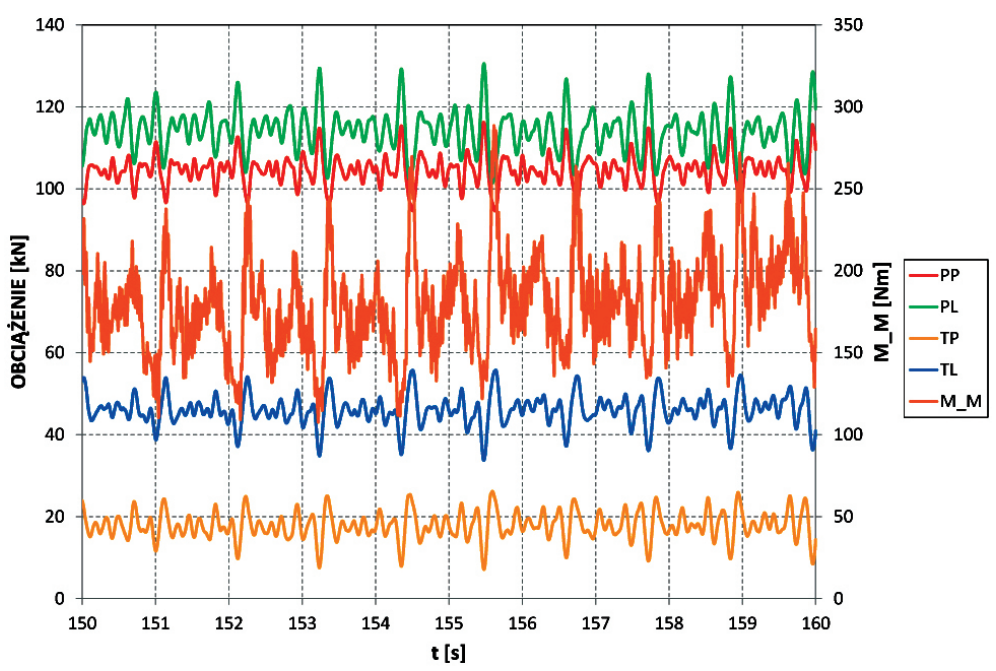

Rys. 9. Dziesięciosekundowy fragment przebiegów czasowych obciażeń dynamicznych podpór kombajnu wynikających z ciężaru kombajnu i procesu urabiania dla skrawu górnego

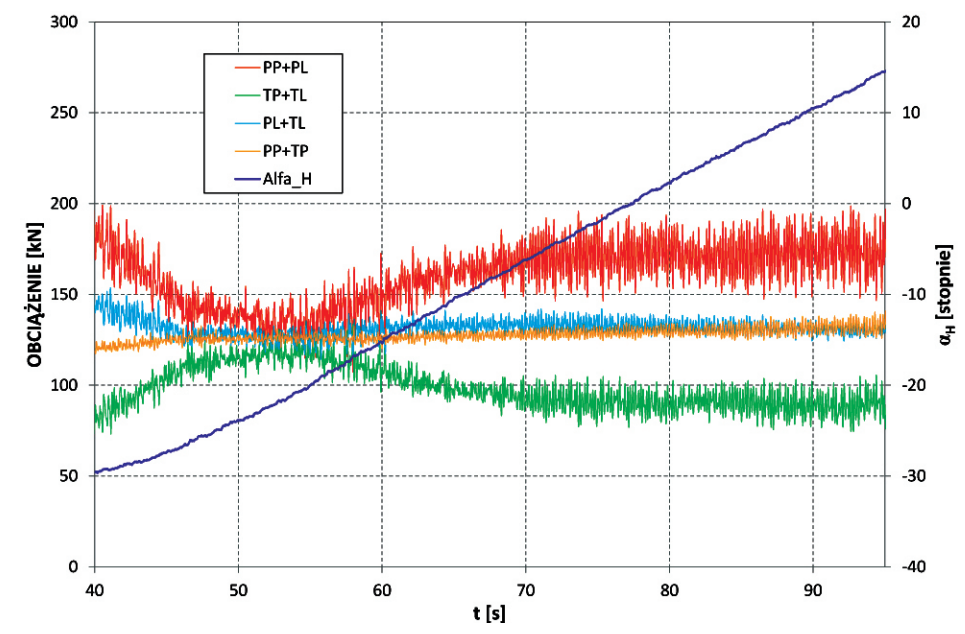

Rys. 10. Przebiegi czasowe obciążeń dynamicznych podpór przednich $(P P+P L)$ i tylnych $(T P+T L)$ oraz prawych $(P P+T P) i$ lewych $(P L+T L)$ podczas wykonywania skrawu dolnego

urabiającymi kombajnu istotnie wpływa na wartości i charakter sił prostopadłych do podłoża przenoszonych w punktach podparcia kombajnu. Średnie wartości sumarycznych obciążeń podpór przednich $(\mathrm{PP}+\mathrm{PL})$ i tylnych (TP+TL) zmieniają się w dużym stopniu ze względu na zróżnicowane obciążenie układu urabiania. Istotnie wzrasta przy tym wartość sumarycznych obciążeń podpór tylnych (TP+TL), która w 55 sekundzie pomiaru niemal zrównuje się z wartością sumarycznych obciążeń podpór przednich (PP+PL).

Odejmując wartości obciążeń wywołanych ciężarem kombajnu od wartości zmierzonych obciążeń w podporach $\mathrm{w}$ trakcie urabiania, wyznaczono siły przenoszone na podłoże wywołane procesem urabiania. Wykorzystując zarejestrowany przebieg czasowy zmiany wartości kąta wychylania wysięgnika w płaszczyźnie równoległej do spągu i wyznaczone wcześniej zależności sumarycznych obciążeń podpór przednich i tylnych kombajnu w funkcji tego kąta, uzyskano przebiegi czasowe obciążeń podpór wynikające tylko z procesu urabiania podczas wykonywania skrawu dolnego (rys. 11). Podobnie, jak to miało miejsce w przypadku skrawu górnego siły oporu urabiania, działające na noże skrawające podczas wykonywania skrawu dolnego, wpływają na zwiększenie sumarycznego obciążenia podpór tylnych i odciążenie podpór przednich. Efekt ten jest jednak większy niż podczas realizacji skrawu górnego. Sumaryczne odciążenie podpór przednich wynikające z procesu urabiania osiąga w tym przypadku wartość $-100 \mathrm{kN}$ (jest zwrócona pionowo w górę), zaś dla podpór tylnych dochodzi do $+75 \mathrm{kN}$. Średnie wartości obciążenia podpór tylnych i odciążenia podpór przednich są przy tym proporcjonalne do wartości momentu obrotowego $M_{M}$ silnika układu urabiania (przebieg w kolorze brązowym na rysunku 11). 


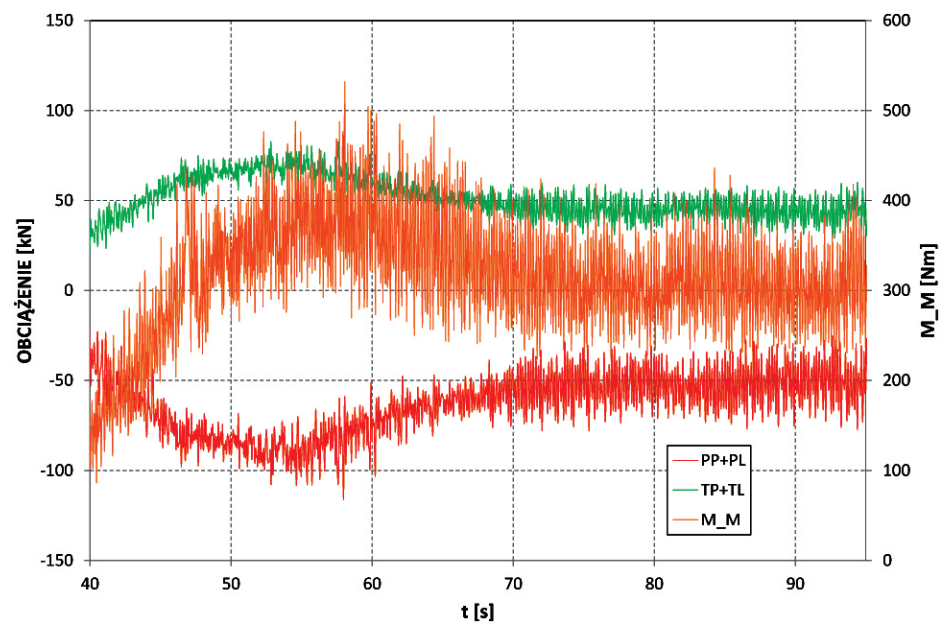

Rys. 11. Przebiegi czasowe obciążeń dynamicznych podpór przednich $(P P+P L)$ i tylnych $(T P+T L)$ wynikające z procesu urabiania dla skrawu dolnego

Ze względu na niskie położenie wysięgnika przy wykonywaniu skrawu dolnego $\left(\alpha_{V}=-15^{\circ}\right)$ wpływ momentu obrotu wysięgnika na rozkład reakcji prostopadłych do podłoża po lewej i prawej stronie kombajnu $(\mathrm{PL}+\mathrm{TL}$ oraz $\mathrm{PP}+\mathrm{TP})$ jest mały. $\mathrm{W}$ rezultacie o przebiegu tych reakcji decyduje składowa pionowa wypadkowej reakcji od urabiania (rys. 12).

Drgania sumarycznych sił obciążających podpory lewe i prawe charakteryzują się mniejszą zmiennością niż obciążenia podpór przednich i tylnych. Wynika to z sumowania się sił reakcji z poszczególnych podpór.

Dla 10-sekundowego fragmentu pomiaru przedstawiono przebiegi czasowe obciążeń prostopadłych do podłoża oddzielnie dla wszystkich podpór (rys. 13). Podobnie jak w przypadku skrawu górnego również w przypadku skrawu dolnego drgania sił obciążających podpory w płaszczyźnie prostopadłej do podłoża charakteryzują się wyraźną powtarzalnością o okresie równym czasowi obrotu głowicy i zbliżonym zakresem zmienności. Drgania sił w podporze przedniej prawej (PP) i podporze przedniej lewej (PL) mają ten sam charakter i są lustrzanym odbiciem przebiegu momentu obrotowego silnika napędu (wzrost momentu obrotowego powoduje chwilowe odciążenie podpór przednich). Drgania sił w podporze tylnej prawej (TP) i podporze tylnej lewej (TL) zmieniają się również w jednakowy sposób. Przebiegi te mają jednak taki sam charakter jak przebieg momentu obrotowego silnika napędu głowic (wzrost momentu obrotowego powoduje chwilowe dociążenie podpór tylnych). Lustrzane odbicie przebiegów sił w podporach przednich i tylnych powoduje zwiększenie amplitud drgań w podporach przednich $(\mathrm{PP}+\mathrm{PL})$ i tylnych $(\mathrm{TP}+\mathrm{TL})$, zaś zmniejszanie amplitud drgań w podporach prawych $(\mathrm{PP}+\mathrm{TP})$ i lewych (PL+TL).

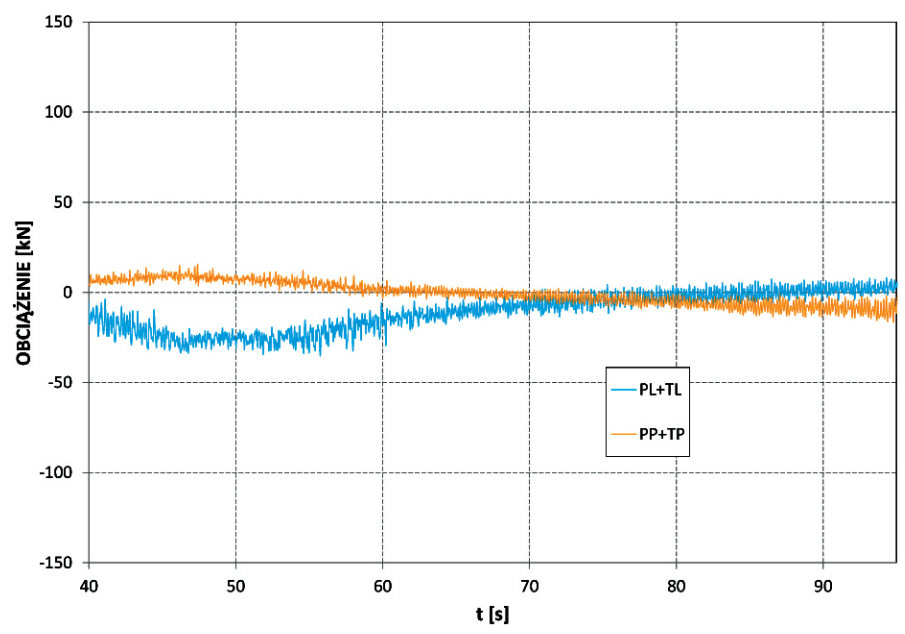

Rys. 12. Przebiegi czasowe obciażeń dynamicznych podpór prawych $(P P+T P)$ i lewych $(P L+T L)$ wynikajace z procesu urabiania dla skrawu dolnego 


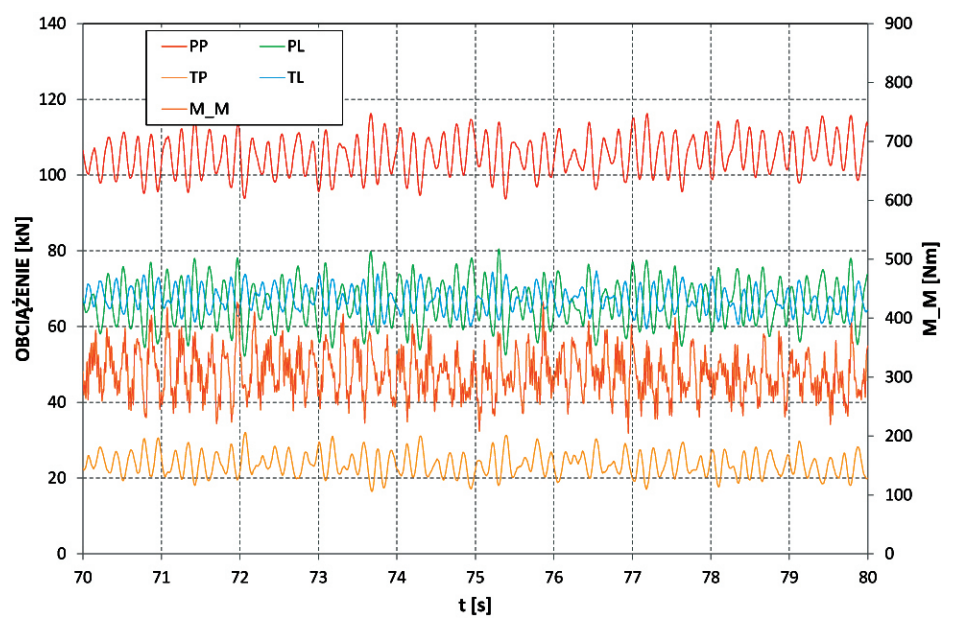

Rys. 13. Dziesięciosekundowy fragment przebiegów czasowych obciażeń dynamicznych podpór kombajnu wynikajacych z ciężaru kombajnu i procesu urabiania dla skrawu dolnego

\section{PODSUMOWANIE}

Pomiary sił oddziaływania dynamicznego wysięgnikowego kombajnu chodnikowego na podłoże zostały przeprowadzone na stanowisku badawczym w Hali Technologicznej Wydziału Górnictwa i Geologii Politechniki Śląskiej. Dokonano ich w trakcie urabiania bloku wykonanego z materiałów ekwiwalentnych (mas cementowo-piaskowych o różnej wytrzymałości na ściskanie) kombajnem chodnikowym R-130 (prod. Famur S.A.).

W celu identyfikacji rozkładu reakcji przenoszonych na podłoże kombajn został posadowiony na zespole podpór rozmieszczonych po dwie na każdej stronie kombajnu. Wyznaczono sumę obciążeń w podporach przednich $(\mathrm{PP}+\mathrm{PL})$ i tylnych $(\mathrm{TP}+\mathrm{TL})$, co pozwala wyznaczyć położenie środka ciężkości kombajnu względem podpór przednich oraz sumę obciążeń w podporach prawych $(\mathrm{PP}+\mathrm{TP})$ i lewych $(\mathrm{PL}+\mathrm{TL})$, co pozwala wyznaczyć odległość środka ciężkości od osi wzdłużnej kombajnu.

Proces urabiania jest źródłem silnych drgań wymuszonych oraz obciążeń dynamicznych, które poprzez więzy konstrukcyjne przenoszone są dalej na obrotnicę, ramę główną kombajnu oraz pozostałe, związane z nią podzespoły kombajnu. Drgania generowane procesem urabiania przez podpory kombajnu przekazywane są na spąg drążonego wyrobiska. Analizie poddano drgania przenoszone na podpory kombajnu prostopadle do podłoża dla dwóch skrawów zrealizowanych w wyniku wychylania wysięgnika od lewej strony w prawo, przy czym pierwszy skraw był skrawem górnym a drugi skrawem dolnym.
Siły od urabiania działające na noże skrawające rozmieszczone na głowicach poprzecznych podczas wykonywania skrawu górnego wpływają na zwiększenie sumarycznego obciążenia podpór tylnych i odciążenie podpór przednich. Średnia wartość obciążenia podpór tylnych i odciążenia podpór przednich jest proporcjonalna do wartości momentu obrotowego silnika układu urabiania. W celu określenia wpływu procesu urabiania na siły przenoszone na podłoże od wartości zmierzonych obciążeń w podporach $w$ trakcie urabiania odseparowano obciążenie wywołane ciężarem kombajnu. Siły urabiania działające na noże skrawające rozmieszczone na głowicach poprzecznych podczas wykonywania skrawu dolnego wpływają na zwiększenie sumarycznego obciążenia podpór tylnych i odciążenie podpór przednich w znacznie większym stopniu niż podczas realizacji skrawu górnego.

Zarówno dla skrawu górnego, jak i dla skrawu dolnego drgania sił obciążających podpory w płaszczyźnie prostopadłej do podłoża charakteryzują się zbliżonym zakresem zmienności i wyraźną powtarzalnością o okresie równym czasowi obrotu głowicy urabiającej. Drgania sił w podporze przedniej, prawej i lewej, mają ten sam charakter i są lustrzanym odbiciem przebiegu momentu obrotowego silnika napędu głowic (wzrost momentu obrotowego powoduje chwilowe odciążenie podpór przednich). Natomiast drgania sił w podporze tylnej, prawej i lewej, mają taki sam charakter, jak przebieg momentu obrotowego silnika napędu głowic (chwilowy wzrost momentu obrotowego powoduje chwilowe dociążenie podpór tylnych). 


\section{Podziękowania}

Praca zrealizowana w ramach projektu pt. „Sterowanie ruchem głowic urabiających kombajnu chodnikowego dla potrzeb obniżenia energochłonności urabiania i obciążeń dynamicznych" dofinansowanego ze środków Narodowego Centrum Badań i Rozwoju w ramach Programu Badań Stosowanych (umowa nr PBS3/B2/15/2015).

\section{Literatura}

[1] Dolipski M., Cheluszka P.: Dynamika układu urabiania kombajnu chodnikowego, Wydawnictwo Politechniki Śląskiej, Gliwice 2002.

[2] Lansheng Zhang, Yuanyu Zhao, XiushanTang, Qiang Liu, Miao Cao, Miao Wu.: Load Spectrum Research of Roadheader Cutting Header based on Rain Flow Method, w: Proceedings of 2016 International Congress on Computation Algorithms in Engineering (ICCAE 2016), June 25-26 2016, Bangkok, Thailand, 401-406.

[3] Wei Wang, Lin Yan, Tianzheng Wang, Shaoping Guan, Chao Zhang, Ying Zhang, Dawei Wang: Dynamic load identification method of rock roadheader using multi neural network and evidence theory, w: Proceedings on 2016 IEEE International Conference on Mechatronics and Automation, August 7-10 2016, Harbin, China, 1238-1243.

[4] Yi Liu, Yang Gao, Yingying Zhang, Jiaxing Fu, Chuanhui Huang: Working Vibration Analysis of the Bearing Plate on Roadheader Test Bed, „MATEC Web of Conferences” 2015, 25, 03019: 6 .

[5] Zhao Xuelei, Liu He, Li Weitao: Load Torque Observer for Cutting Motor of Roadheader Based on PLL, w: Proceedings of Third International Conference on Measuring Technology and Mechatronics Automation, January 6-7 2011, Shangshai, China, 476-480.

[6] Kogut J.: Analiza spektrum odpowiedzi drgań drogowych, Politechnika Krakowska, Kraków 1999 [praca doktorska].
[7] Mrozek D.: Nieliniowa analiza numeryczna dynamicznej odpowiedzi uszkodzonych budynków, Politechnika Śląska, Gliwice 2010 [praca doktorska].

[8] Nader M.: Oddziaływania dynamiczne wybranych środków transportu na budynki i ludzi, na przykładzie badań węzła komunikacyjnego, w: Proceeding of International Scientific Conference „Transport of the 21st century”, 18-21.09.2007, Stare Jabłonki, Poland, 2007.

[9] Burnos P.: Autokalibracja systemów ważących pojazdy samochodowe $w$ ruchu oraz analiza I korekcja wplywu temperatury na wynik ważenia, AGH, Kraków 2009 [praca doktorska].

[10] Wiśnicki B., Wolnowska A.: The systems of automatic weight control of vehicles in the road and rail transport in Poland, „LogForum” 2011, 7, 3, 3: 25-33. http://www.logforum.net/ vol7/issue3/no3.

[11] Postolache O., Girão P.S.: Calibration and application of a pressure mapping sensor, w: Proceedings of IMEKO 2010 TC3, TC5 and TC22 Conferences „Metrology in Modern Context”, November 22-25 2010, Pattaya, Chonburi, Thailand, 329-332.

[12] Cheluszka P., Remiorz E.: Test stand for determining dynamic loads transmitted to the floor while roadheader operation, „Technicka Diagnostika” 2016, 25, 1: 62-70.

[13] Dolipski M., Sobota P.: Badania zmiany położenia środka ciężkości kombajnu chodnikowego, „Maszyny Górnicze” 1998, 72: 23-29.

dr hab. inż. PIOTR CHELUSZKA, prof. PŚ dr inż. PIOTR SOBOTA

mgr inż. GRZEGORZ GEUSZEK

Katedra Mechanizacji i Robotyzacji Górnictwa

Wydziat Górnictwa i Geologii

Politechnika Ślaska

ul. Akademicka 2, 44-100 Gliwice

\{Piotr.Cheluszka, Piotr.Sobota,

Grzegorz.Gluszek\}@polsl.pl 